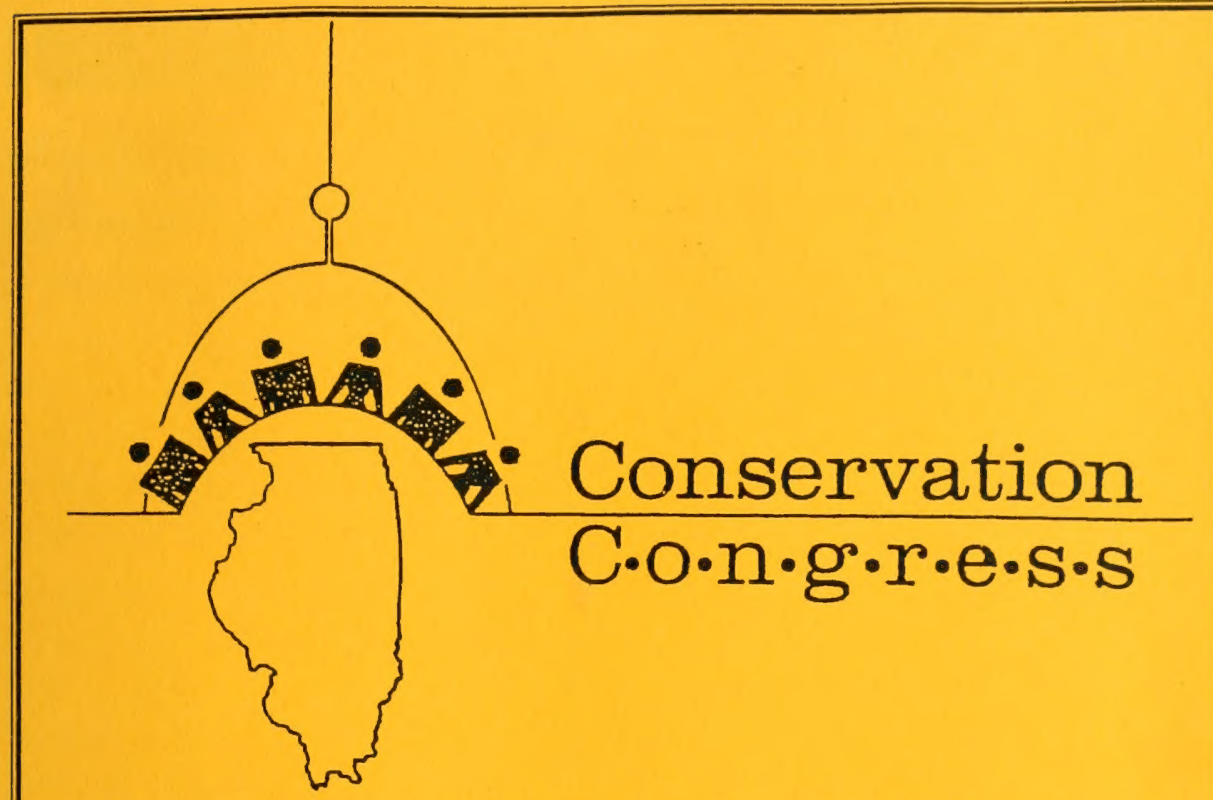

DEPARTMENT OF CONSERVATION

\title{
ANALYSIS OF RECOMMENDATIONS
}

\section{DEPOSITORY}

\section{JUL 281995}

UNIVERSITY OF ILLINOIS AT URBANA.CHAMPAIGN

Brent Manning, Director John Comerio, Deputy Director Bruce Clay, Assistant Director
ASSEMBLY OF DELEGATES

October 2, 1994 
NOTICE: Return or renew all Library Materials! The Minimum Fee for each Lost Book is $\$ 50.00$.

The person charging this material is responsible for its return to the library from which it was withdrawn on or before the Latest Date stamped below.

Theft, mutilation, and underlining of books are reasons for disciplinary action and may result in dismissal from the University.

To renew call Telephone Center, 333-8400

UNIVERSITY OF ILLINOIS LIBRARY AT URBANA-CHAMPAIGN

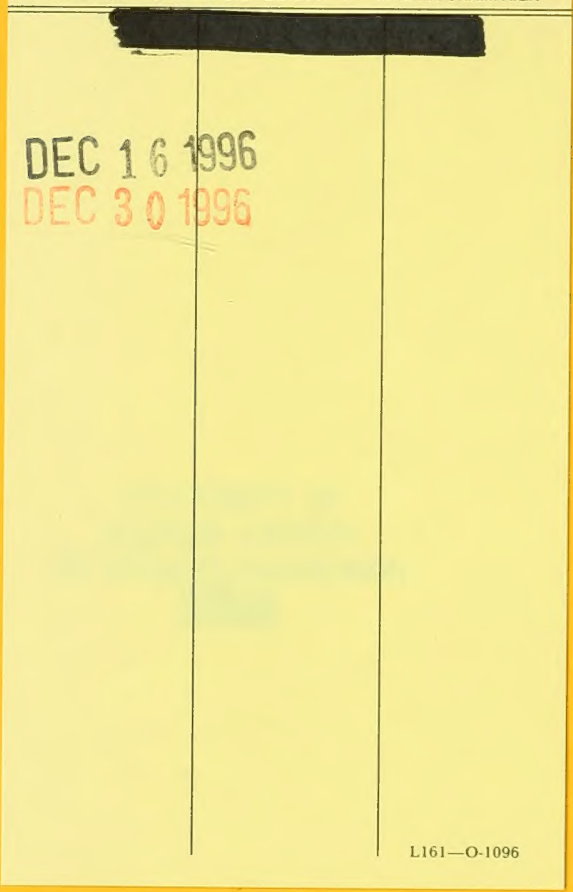




\section{OUTDOOR RECREATION COMMITTEE}

OR-1

OR-2

OR-3

OR-4 4

OR-5

\section{LAND MANAGEMENT COMMITTEE}

LM-1 6

LM-4 7

LM-5 8

LM-9

\section{PUBLIC INVOLVEMENT COMMITTEE}

PI-1

PI-3

PI-4

PI-6

PI-8

\section{TRAILS \& GREENWAYS COMMITTEE}

TG-1 15

TG-2 16

TG-3 18

TG-6

Note: This report contains the Department of Conservation's analysis of each recommendation from Conservation Congress II, based upon agency review of the complete recommendation from the Congress committees and approved by the Assembly of Delegates. Those recommendations were presented to Conservation Director Brent Manning at the close of the Congress and were distributed to the public at that time. Copies of the complete recommendations can be obtained by calling 21 7/782-4963 or by writing to Conservation Congress, Illinois Department of Conservation, 524 S. Second St., Room 510, Springfield, IL 62701-1787. 


\section{EDUCATION COMMITTEE}

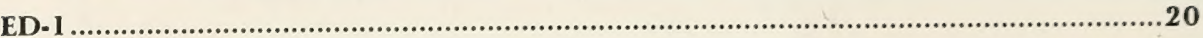

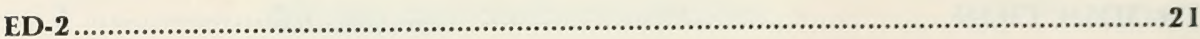

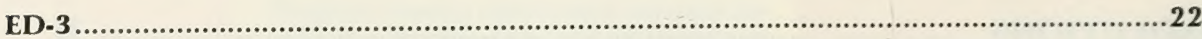

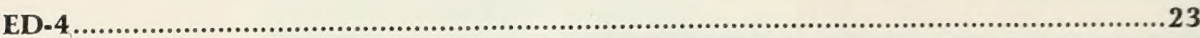

\section{FUNDING COMMITTEE}

F-1/2

F-5

F-7

F-8

\section{APPENDIX}

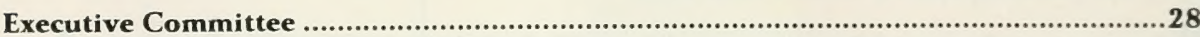

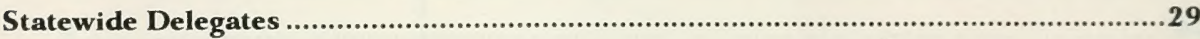

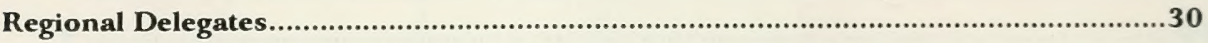

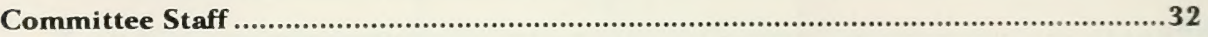

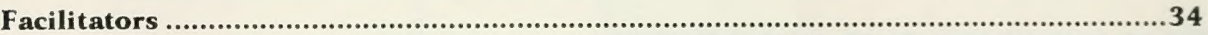

The Illinois Department of Conservation receives Federal financial assistance and therefore must comply with the Federal anti-discrimination laws. In compliance with the Illinois Human Rights Act, the Illinois Constitution. Title VI of the 1964 Civil Rights Act, Section 504 of the Rehabilitation Act of 1973 as amended, and the U.S. Constitution, the Illinois Department of Conservation does not discriminate on the basis of race, color, sex, national origin, age or disability. If you believe you have been discriminated against in any program, activity, or facility, please contact the Equal Employment Opportunity Officer, bepartment of Conservation, 524 S. Second St., Springfield, IL. $62701-1787,217 / 782-7616$ (TDD 217/782-9175), or the Office of Human Resources, U.S. Fish and Wildlife Service, Washington, D.C. 20240.

Department of Conservation information is available to the hearing impaired by calling DOC's Telecommunications Device for the Deaf: 217/782. 9175. The Illinois Bell Relay Number is $800 / 526-0844$.

Printed by the Authority of the State of Illinois

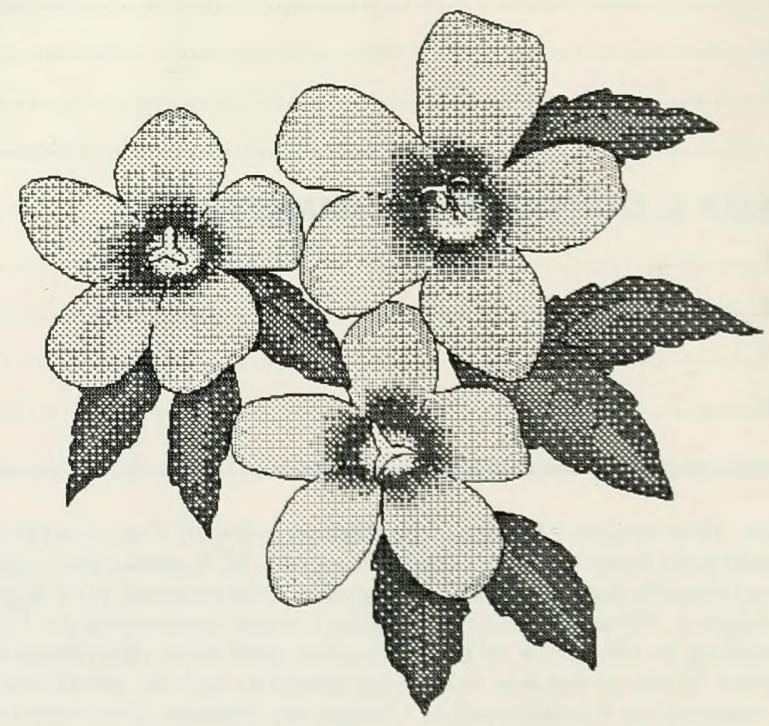

Printed on Recycled Paper 


\section{INTRODUCTON}

Conservation Congress is an unprecedented constituency outreach effort to bring together representatives of all the interest groups that the Department of Conservation serves. The process provides an opportunity for the constituents to recommend actions to address issues of critical importance to constituents.

Caucuses are held in each of the Department's five administrative regions. Constituent group representatives identify and prioritize issues to be addressed by the Congress. Potential solutions to those issues also are generated at the caucuses. Seventy delegates are elected to represent regional interests at the Congress, and 48 groups are invited by Director Brent Manning to name a delegate to represent that group's interests at the Congress - for a total of 118 delegates.

Issues are assigned to one of six work teams, composed of statewide and regional delegates and representatives of groups that participated in the regional caucuses. These teams refine and elaborate potential solutions generated at the caucuses. Work teams prioritize the recommendations, which are then assigned to one of six committees at Conservation Congress.

Conservation Congress convenes in Springfield. The weekend is modeled on the legislative process, giving constituents an opport unity to be directly involved in governmental decision-making. Delegates are assigned to committees where they review work team recommendations - accepting, rejecting or amending those recommendations and prioritizing final recommendations, which are voted on during the Assembly of Delegates on Sunday.

On the final day of the Congress, delegates assemble in the House of Representatives chamber to vote on committee recommendations. The final recommendation package is presented to the Director for review and implementation when possible.

The first Conservation Congress convened Feb. 5, 1993. Thirtynine recommendations were passed during the Assembly of Delegates. Many of those recommendations have been implemented, including holding a second Conservation Congress Sept. 30 - Oct. 2, 1994 , where 26 recommendations were passed.

This booklet contains the recommendation statements from the 26 recommendations from Conservation Congress II, along with the Department's responses. The voting record on each recommendation is shown. Delegates are listed by last name only, but you can further identify the delegates in the Appendix. Only "Yes" votes are recorded, delegates either voted for a recommendation or did not vote.

Many volunteer hours are involved in Conservation Congress, from both the staff and the constituents. That effort has resulted in a better understanding by all participants of the importance of planning for the future of our natural resources and the recreational opportunities associated with those resources. The Department of Conservation thanks all who participated.

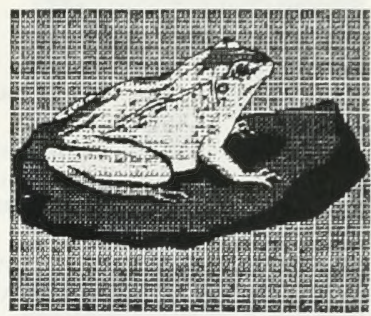




\section{RESOLUTION I Appreciation}

WHEREAS, Director Brent Manning has taken a futuristic concept and developed it into a model for the entire United States, and

WHEREAS, Claudia Emken has tirelessly brought together the many concepts and constituency groups with a contagious enthusiasm which spreads to all who meet her, and

WHEREAS, the many IDOC staff members have given of their own time not only during this week but for the last 18 months, and

WHEREAS, Executive Committee Chairman John Schmitt and his committee have given of their time and energies since the last Conservation Congress,

The delegates of the 1994 Conservation Congress do hereby salute and applaud your dedication and overt efforts to promote harmony, constructive thoughts and actions of our many and varied constituency groups. The plants, animals and citizens of Illinois will reap the benefits not only today but in the future years to come.

\section{RESOLUTION II Midewin National Tallgrass Prairie}

We, the delegates of Illinois' Conservation Congress II, composed of more than 400 constituency groups, representing the 11.5 million citizens of Illinois, and dedicated to natural resource conservation and outdoor recreation provision, applaud Congressman George Sangmeister and Governor Jim Edgar and join with them in support of establishing the Midewin National Tallgrass Prairie on the site of the Joliet Army Arsenal Plant in Illinois.

WHEREAS, Illinois is currently ranked 48th among the 50 states in per capita public open space, and

WHEREAS, creation of this national grassland would restore up to 19,000 acres of prairie and preserve habitat for 16 state endangered and threatened species, 17 species on the Illinois watch list, and five federal candidate species, and

WHEREAS, loss of tallgrass prairie has been greater than the decline in acreage of any other major ecosystem in North America and the Joliet Arsenal presents a unique opportunity to restore now-rare native tallgrass prairie ecosystems and to preserve the region's biodiversity, and

WHEREAS, a public-private partnership has been formed to oversee site cleanup and to explore innovative technologies for environmental remediation that could improve environmental cleanup efforts nationally, and

WHEREAS, creation of the Midewin National Tallgrass Prairie is an unparalleled conservation opportunity for the nation and particularly for the more than eight million citizens that live within 50 miles of the proposed national prairie,

BE IT THEREFORE RESOLVED that it is in the best interest of the citizens of the State of Illinois and the United States of America that Congress expeditiously authorize the conversion of the Joliet Army Arsenal Plant to the Midewin National Tallgrass Prairie.

\section{RESOLUTION III Conservation 2000}

We, the delegates of Illinois' Conservation Congress II, composed of more than 400 constituency groups, representing the 11.5 million citizens of Illinois, and dedicated to natural resources conservation and outdoor recreation provision, applaud Governor Jim Edgar's Conservation 2000 initiative.

WHEREAS, the Governor Edgar's Water Resources and Land Use Priorities Task Force, Conservation Congress I, and other study reports and study groups have identified many of the problems addressed by the Conservation 2000 initiative as critical to the conservation of the state's natural resources,

BE IT THEREFORE RESOLVED, that it is in the best interest of the citizens of the State of Illinois that Governor Edgar and the General Assembly pass, the broad based conservation initiative, Conservation 2000 . 


\section{INCREASE HUNTING, FISHING AND TRAPPING AREAS (OR-1)}

Recommendation: In order to increase hunting, fishing
and trapping on existing properties and provide addi-
tional areas for hunting, fishing and trapping, we recom-
mend the following:

1. Expand IDOC's educational efforts to better inform the general public, and Illinois' school children in particular, about the principles of conservation and wildlife management, placing special emphasis upon the importance of responsibly regulated hunting, fishing and trapping. Accomplish this through the development of a "Conservation Syllabus" available to all school children in Illinois, and through an expansion of youth hunting and fishing seminars, clinics and classes at IDOC sites using volunteer instructors where possible. To further support IDOC's efforts toward teaching the youth of Illinois proper hunting ethics, non-hunting youth at least 10 years of age should be permitted to accompany their parent(s) or guardian on hunts at IDOC-controlled sites.

2. Initiate cooperative efforts between IDOC and federal, state, county and local entities to survey existing publicly-owned properties to identify areas for expanded hunting, fishing and trapping opportunities as part of a responsible wildlife management plan.

3. Restore the IDOC Heavy Equipment Crew (HEC) to pre-1992 operational levels and expand as needed to ensure that fish and wildlife habitat restoration and recreation projects are completed efficiently and cost-effectively.

\section{IDOC RESPONSE:}

1. The newest education kit, "Resource Conservation," focuses on resource management and potential use of Illinois' renewable natural resources, including hunting, fishing and trapping. Discussions on the "Conservation Syllabus" have occurred with the Outdoor Recreation Committee chair to further clarify the intent of this part of the recommendation.

Currently, non-hunting youth are allowed to accompany their parents or guardians on most IDOC managed sites. Provisions will be made for non-hunting youth under 16 to accompany a supervising adult on duck, goose, deer and turkey permit areas. At intensively hunted IDOC dove permit sites, young hunters can be afield as part of the hunter quota. A pilot program will be considered which will cut back the quota at controlled pheasant hunting areas, one or two days during the season, and allow non-hunting youth to accompany a supervising adult. The Department will continue its special youth hunts for doves, pheasants, upland game, geese and ducks and will encourage youth to participate in these hunts.

2. The Division of Land Acquisition recently completed an inventory of state-owned sites. A pilot project on habitat enhancement and wildlife refuge is under consideration on Department of Corrections property in Vandalia. While hunting, fishing or trapping on Corrections' property is not permitted, opportunities will be expanded in the area through improved habitat. Additional opportunities will be pursued with the Departments of Corrections and Agriculture.

3. Restoration and expansion of the Heavy Equipment Program is a high priority of the agency. Investment strategies have been shared with constituency leaders and have been endorsed.

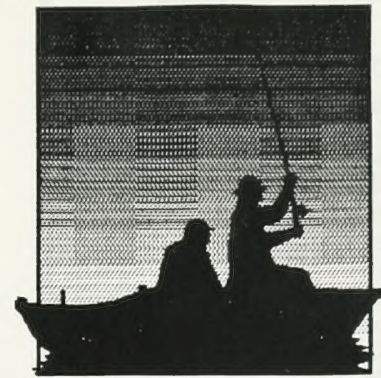

\section{OR-1 VOTING}

Delegates in favor (94):

Adelmann, Aitken, Armer, Baker, Bamberger, Barkley, Beck, Becker, Beezhold, Bishop, Black, Bower, Brueckner, Buenting, Bullard, Bunt, Byrns, Caveny, Coates, Crawford, Desulis, Dirksen, Eichelkraut, Erickson, Eyre, Funk, Gabriel, Gale, Garner, Graeff, Gross, Gruber, Guthrie, Haertel, Hagan, Hamberg, Hambly, Harney, Hartman, Hooser, Hunsaker, Jacobs, Jessen, Johnson, Jorstad, Keitzman, Kielsmeier, Konsis, Kozicky, Kutska, Lamb, Lechner, Lehman, Ludwig, Lymenstull, McAllister, McFarlane, Mickelson, Montgomery, R. Morris, Nix, Noe, Norman, Padovan, Peach, Pientka, Platt, Potts, Reardanz, Roehll, Rogers, Rolfe, Romano, Schmitt, Schreiber, Shimp, Skelly, Sliwa, Smithson, Spada, Spale, Spaniol, Sparr, J. Stewart, Struck, Tetzlaff, Trimble, Turner, Walker, Walters, Werthwein, White, Yanor, Young.

Delegates not voting (23): Caffee, Campbell, Carey, Deneen, Dickey, Dougherty, Falco, Marquardt, Martin, Mills, Mittage, A. Morris, Penberthy, Roth, Schwartz, Siegner, Silberhorn, Smith, L. Stewart, Stumpf, Veugeler, Weirich, Yacalavitch. 
OUTDOOR RECREATON COMMULITE

\section{OR-2 VOTING}

Delegates in favor (90):

Adelmann, Aitken, Armer, Bamberger, Barkley, Beck, Becker, Beezhold, Bishop, Black, Bower, Brueckner, Buenting, Bunt, Byrns, Caffee, Campbell, Caveny, Crawford, Deneen, Desulis, Dickey, Dirksen, Eichelkraut, Erickson, Eyre, Funk, Gale, Garner, Graeff, Gross, Gruber, Guthrie, Haertel, Hagan, Hamberg, Hambly, Harney, Hooser, Hunsaker, Jacobs, Jessen, Jorstad, Keitzman, Kielsmeier, Konsis, Kozicky, Kutska, Lamb, Lechner, Lehman, Ludwig, Lymenstull, McAllister, McFarlane, Montgomery, R. Morris, Nix, Noe, Norman, Padovan, Peach, Pientka, Platt, Potts, Reardanz, Roehll, Rogers, Romano, Roth, Schmitt, Silberhorn, Skelly, Sliwa, Smith, Smithson, Spada, Spale, Sparr, J. Stewart, Struck, Stumpf, Tetzlaff, Trimble, Walker, Walters, Werthwein, White, Yanor, Young.

Delegates not voting (27): Baker, Bullard, Carey, Coates, Dougherty, Falco, Gabriel, Hartman, Johnson, Marquardt, Martin, Mickelson, Mills, Mittage, A. Morris, Penberthy, Rolfe, Schreiber, Schwartz, Siegner, Shimp, Spaniol, L. Stewart, Turner, Veugeler, Weirich, Yacalavitch.

\section{RESTORE AND EXPAND THE CONTROLLED PHEASANT HUNTING PROGRAM (OR-2)}

Recommendation: Restore and expand the controlled pheasant hunting program on the 16 state sites to the pre-1990 levels. Raise the daily fee to reflect production costs, but not to exceed $\$ 20$ by 1996 or $\$ 25$ by the year 2000.

\section{IDOC RESPONSE:}

Results from the privatization program will be evaluated before a final decision on the controlled pheasant hunting program will be made.

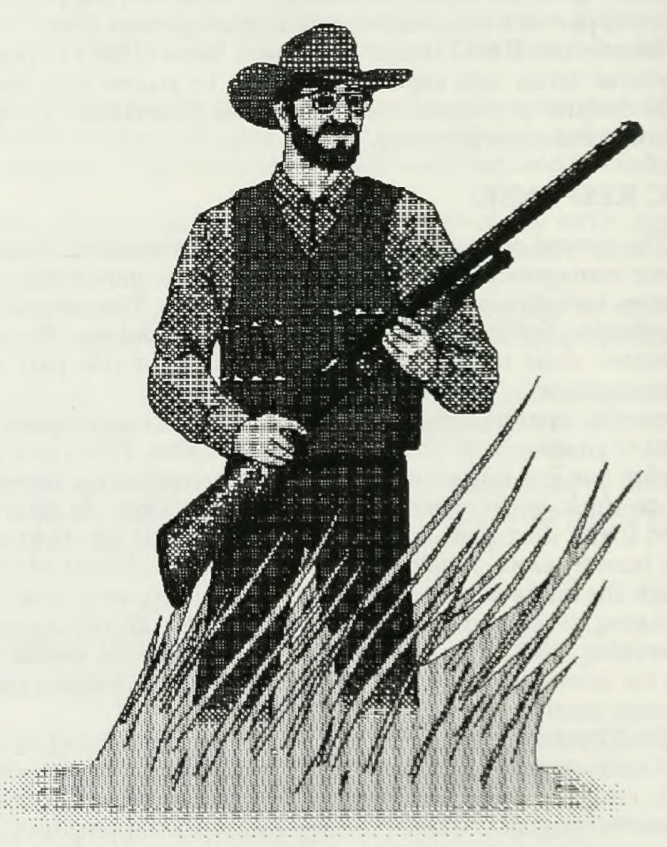


REVISE THE DEER PERMIT AND PERMITS FOR PERSONS WITH DISABILITIES SYSTEMS (OR-3)

\section{Recommendation: Revise the deer permit and disabled hunting permit systems by:}

1. Providing over-the-counter deer archery permits at selected sites and making them a one-time combination purchase of one either-sex permit plus one antlerless only permit.

2. Requiring all bowhunters less than 16 years of age to have completed a bowhunting safety course similar to that in Iowa, as instructors and materials become available.

3. Expanding the number of sites in the Quality Deer Program and doing a detailed study of the efficacy of this program.

4. Expanding crossbow hunting opportunities for persons with disabilities to other species such as small game and upland game. At the same time, assure that this privilege is not abused by listing the disability and expiration date of the condition on the permit.

\section{IDOC RESPONSE:}

1. A proposal for over-the-counter archery deer permit sales is under consideration. The number and type of permits issued will be based on herd status, population objectives and hunter success rates.

2. The IDOC will continue to support and encourage bowhunter education on a volunteer basis. Due to budget constraints, it will not be mandatory at this time.

3. The Joliet Army Arsenal and Heidecke Lake will be added to the Quality Deer Program. It will take several years to see significant results of such a program at the local level.

4. Currently, crossbows can be used by individuals with permanent disabilities which prevent that person from using a bow and arrow to hunt deer; there is no expiration date. The Department recognizes that this issue continues to be a controversy among constituent groups, however it will be further analyzed.

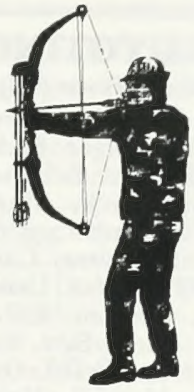

\section{OR-3 VOTING}

Delegates in favor (59):

Armer, Barkley, Beck, Becker, Beezhold, Black, Bower, Brueckner, Buenting, Bunt, Byrns, Carey, Caveny, Coates, Deneen, Desulis, Dickey, Dirksen, Eichelkraut, Erickson, Gale, Garner, Gross, Hagan, Hamberg, Harney, Hooser, Hunsaker, Jacobs, Johnson, Jorstad, Keitzman, Kielsmeier, Lymenstull, McAllister, McFarlane, Montgomery, R. Morris, Nix, Noe, Padovan, Platt, Potts, Reardanz, Rogers, Romano, Silberhorn, Skelly, Smithson, Spada, Spaniol, Sparr, J. Stewart, Tetzlaff, Trimble, Walker, Walters, White, Young.

Delegates not voting (58):

Adelmann, Aitken, Baker, Bamberger, Bishop, Bullard, Caffee, Campbell, Crawford, Dougherty, Eyre, Falco, Funk, Gabriel, Graeff, Gruber, Guthrie, Haertel, Hambly, Hartman, Jessen, Konsis, Kozicky, Kutska, Lamb, Lechner, Lehman, Ludwig, Marquardt, Martin, Mickelson, Mills, Mittage, A. Morris, Norman, Peach, Penberthy, Pientka, Roehll, Rolfe, Roth, Schmitt, Schreiber, Schwartz, Siegner, Shimp, Sliwa, Smith, Spale, L. Stewart, Struck, Stumpf, Turner, Veugeler, Weirich, Werthwein, Yacalavitch, Yanor. 


\section{OR-4 VOTING}

Delegates in favor (98):

Adelmann, Aitken, Armer, Baker, Bamberger, Barkley, Beck, Becker, Beezhold, Bishop, Black, Bower, Brueckner, Buenting, Bullard, Bunt, Byrns, Caffee, Campbell, Coates, Deneen, Desulis, Dirksen, Eichelkraut, Erickson, Eyre, Falco, Gale, Garner, Graeff, Gross, Gruber, Haertel, Hagan, Hamberg, Hambly, Harney, Hooser, Hunsaker, Jacobs, Jessen, Johnson, Jorstad, Keitzman, Kielsmeier, Konsis, Kozicky, Kutska, Lamb, Lechner, Lehman, Ludwig, Lymenstull, Marquardt, McAllister, McFarlane, Mickelson, Mittage, Montgomery, R. Morris, A. Morris, Nix, Noe, Norman, Padovan, Peach, Pientka, Platt, Potts, Reardanz, Roehll, Rogers, Rolfe, Romano, Roth, Schmit, Schreiber, Schwartz, Shimp, Silberhorn, Skelly, Sliwa, Smith, Smithson, Spada, Spale, Sparr, Struck, Stumpf, Tetzlaff, Trimble, Turner, Walker, Walters, Werthwein, White, Yanor, Young.

Delegates not voting (19): Carey, Caveny, Crawford, Dickey, Dougherty, Funk, Gabriel, Guthrie, Hartman, Martin, Mills, Penberthy, Siegner, Spaniol, J. Stewart, L. Stewart, Veugeler, Weirich, Yacalavitch.

\section{UNIFORM SYSTEM FOR RESERVING CAMP SITES (OR-4)}

Recommendation: The Illinois Department of Conservation should develop a uniform system for reserving both individual and group camp sites at the facilities under its operation or the operation of its concessionaires.

\section{IDOC RESPONSE:}

A camping work group, composed of DOC staff, has been assigned to look at improving and expanding the current camping reservation system, changes to be implemented in early 1996.

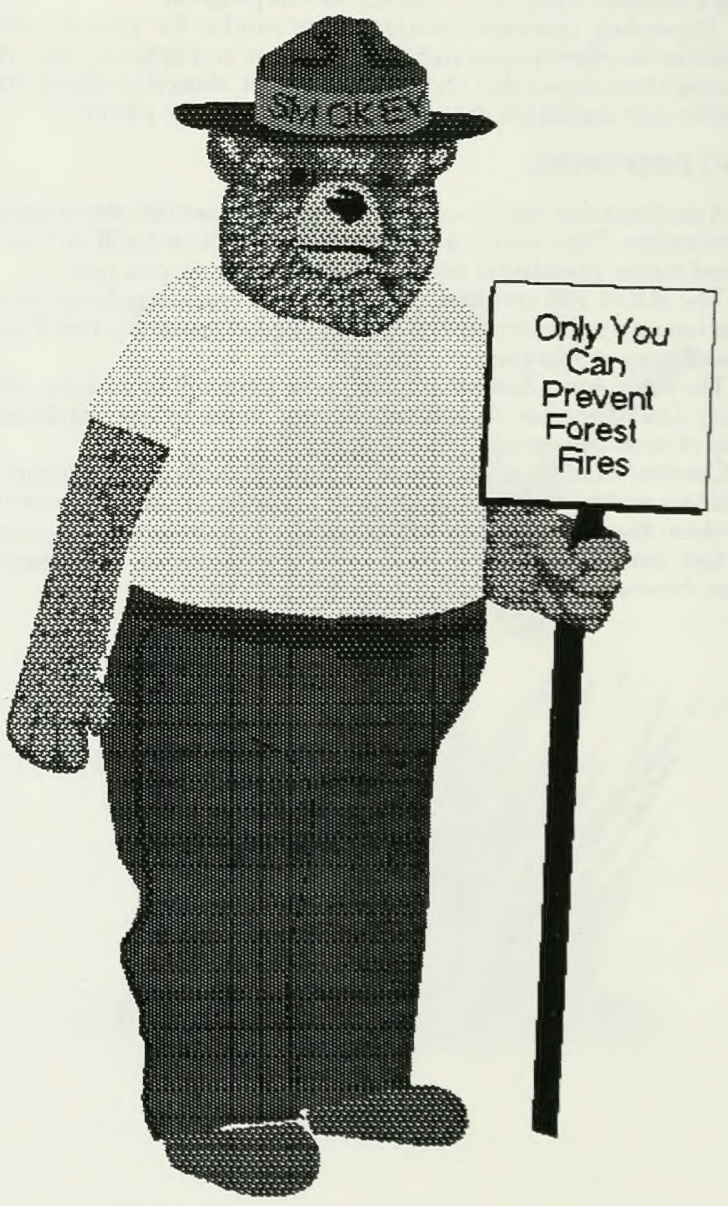




\section{OUMDOOR RECREA UTON OOMMTH TEL}

\section{REVIEW WATERFOWL HUNTING DATES AND ZONES (OR-5)}

Recommendation: Review waterfowl hunting dates and zones to maximize hunter opportunity.

\section{IDOC RESPONSE:}

The waterfow regulations, including dates and bag limits, undergo a public review process, through the Federal Register, every year. 1996 is the earliest that duck zone lines could be changed due to a five-year moratorium. Any changes made would be in effect for another five years before another change could be made. The public will have an opportunity to offer input, beginning with the waterfowl surveys that are taken this year.

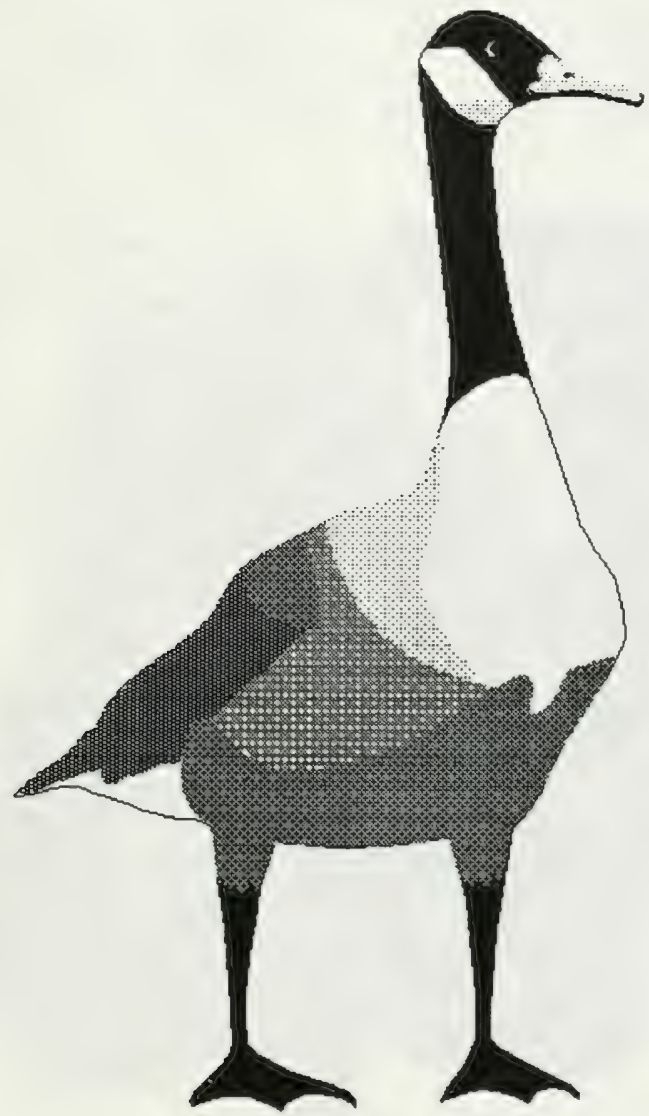

OR-5 VOTING

Delegates in favor (75):

Adelmann, Aitken, Armer, Bamberger, Barkley, Beck, Becker, Beezhold, Bishop, Black, Bower, Brueckner, Buenting, Bunt, Caffee, Carey, Crawford, Deneen, Desulis, Dirksen, Eichelkraut, Erickson, Eyre, Gale, Graeff, Gross, Gruber, Guthrie, Haertel, Hagan, Hamberg, Hambly, Hartman, Hooser, Hunsaker, Jacobs, Jorstad, Keitzman, Kielsmeier, Konsis, Kozicky, Lamb, Lechner, Ludwig, Lymenstull, McAllister, Mickelson, R. Morris, Nix, Noe, Padovan, Peach, Pientka, Reardanz, Roehll, Rogers, Romano, Schmitt, Silberhorn, Skelly, Sliwa, Smithson, Spada, Spaniol, Sparr, J. Stewart, Struck, Stumpf, Trimble, Walker, Walters, Werthwein, White, Yanor, Young.

Delegates not voting (42): Baker, Bullard, Byrns, Campbell, Caveny, Coates, Dickey, Dougherty, Falco, Funk, Gabriel, Garner, Harnev, Jessen, Johnson, Kutska, Lehman, Marquardt, Martin, McFarlane, Mills, Mittage, Montgomery, A. Morris, Norman, Penberthy, Platt, Potts, Rolfe, Roth, Schreiber, Schwartz, Siegner, Shimp, Smith, Spale, L. Stewart, Tetzlaff, Turner, Veugeler, Weirich, Yacalavitch. 


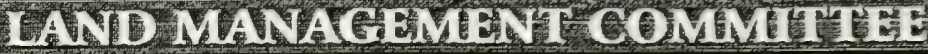

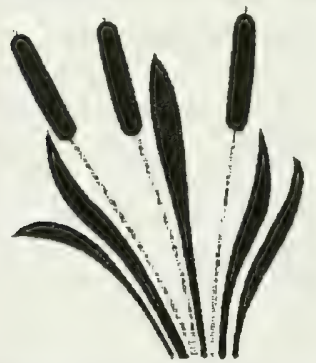

\section{LM-1 VOTING}

Delegates in favor (91):

Adelmann, Aitken, Baker, Bamberger, Beck, Becker, Beezhold, Bishop, Black, Bower, Brueckner, Bullard, Byrns, Caffee, Campbell, Carey, Caveny, Coates, Crawford, Deneen, Desulis, Dickey, Dirksen, Eichelkraut, Erickson, Eyre, Falco, Funk, Gabriel, Gale, Garner, Graeff, Gross, Gruber, Haertel, Hagan, Hamberg, Hambly, Harney, Hooser, Jacobs, Jessen, Johnson, Jorstad, Keitzman, Kielsmeier, Konsis, Kutska, Lamb, Lehman, Ludwig, Marquardt, McFarlane, Mickelson, Mittage, Montgomery, R. Morris, A. Morris, Nix, Noe, Norman, Padovan, Peach, Platt, Potts, Roehll, Rogers, Rolfe, Roth, Schmitt, Schreiber, Schwartz, Shimp, Silberhorn, Skelly, Sliwa, Smith, Smithson, Spale, Spaniol, Sparr, J. Stewart, Struck, Stumpf, Tetzlaff, Trimble, Turner, Walker, Werthwein, Yanor, Young.

Delegates not voting (26): Armer, Barkley, Buenting, Bunt, Dougherty, Guthrie, Hartman, Hunsaker, Kozicky, Lechner, Lvmenstull, Martin, McAllister, Mills, Penberthy, Pientka, Reardanz, Romano, Siegner, Spada, L. Stewart, Veugeler, Walters, Weirich, White, Yacalavitch.

\section{ECOSYSTEM MANAGEMENT (LM-1)}

Recommendation: It is recommended that the IDOC expand staff, technical, financial and incentive programs in all natural resource field-based and land management divisions so as to more rapidly and more completely implement an ecosystem approach to natural resources management. Therein protecting, restoring and enhancing biodiversity by increasing stewardship capabilities, natural area and stream corridor management with willing private property owners and on public lands.

\section{IDOC RESPONSE:}

The Department is committed to ecosystem management. Expansion of current efforts will occur when Conservation 2000 is passed.

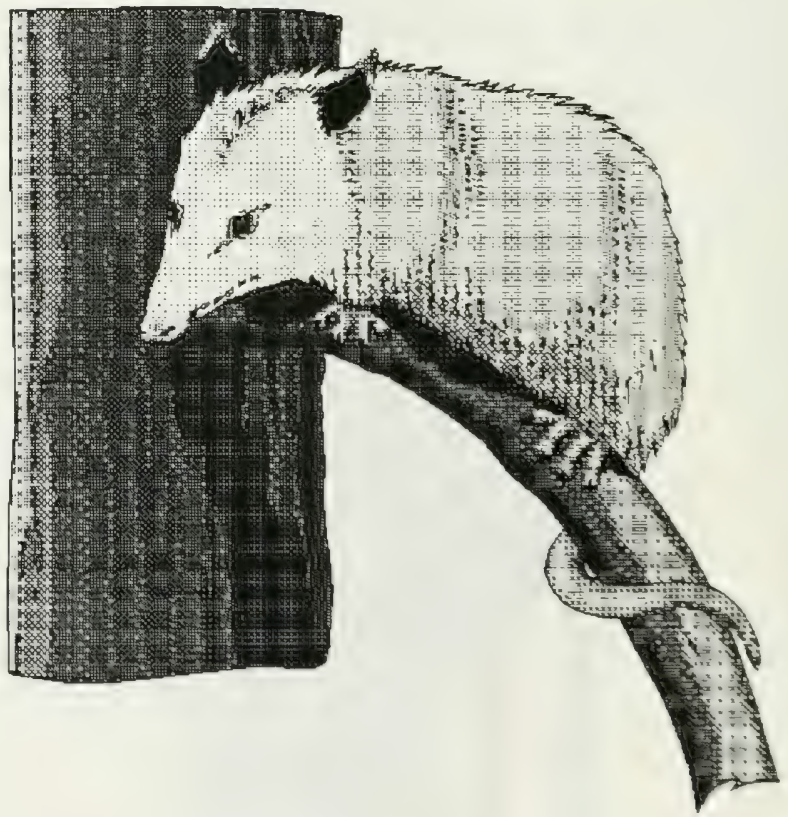




\section{LAND MANAGEMENS COMNU TOE}

\section{ESTABLISH FOREST AND GRASSLAND MACROSITES (LM-4)}

Recommendation: The IDOC should work to establish a system of forest and grassland macrosites to provide habitat for all area-sensitive species. Macrosites would provide the opportunity to establish well managed sustainable ecosystems. To achieve this recommendation the IDOC should:

1. Work with other willing landowners, public and private, including USFS, USFWS, DOD, other federal, state and local agencies.

2. Pay special attention to, and place particular emphasis on, protecting the habitat value of forest ecosystems of 500 acres or larger.

3. Manage IDOC orvned lands as sustainable ecosystems.

The goal for each macrosite should be to assure biological diversity, ecological processes, biotic communities, habitats for all area-sensitive species and long-term health of all native species.

Since immediate opportunities to establish macrosites are limited to a few areas on public lands, smaller reserves also should be established. The goal of smaller areas would be to provide biological corridors and protect remaining contiguous forest and grassland tracts.

\section{IDOC RESPONSE:}

Macrosite establishment is an ongoing commitment of the agency. Implementing TG1, LMI and TG3 are components of the macrosite program and dependent upon passage of Conservation 2000.

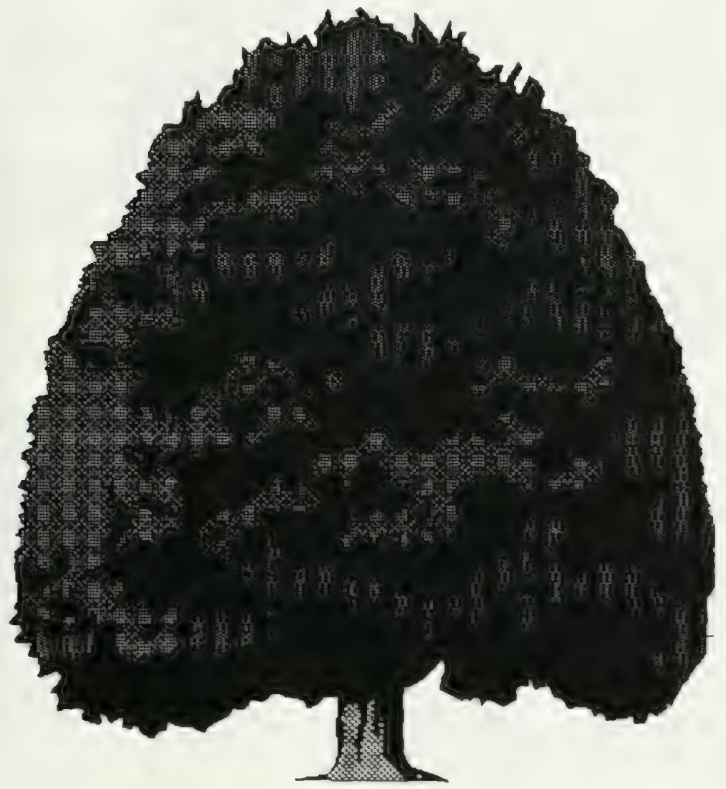

\section{LM-4 VOTING}

Delegates in favor (81):

Adelmann, Aitken, Baker, Bamberger, Barkley, Becker, Bishop, Black, Brueckner, Buenting, Bullard, Bunt, Byrns, Caffee, Campbell, Caveny, Coates, Crawford, Deneen, Desulis, Dickey, Dirksen, Eichelkraut, Evre Falco, Gabriel, Garner. Graeff, Gross, Gruber, Guthrie, Haertel, Hagan, Hamberg, Hambly, Harney, Hooser, Jacobs, Jessen, Johnson, Jorstad, Kielsmeier, Konsis, Kutska, Lamb, Lechner, Lehman, Ludwig, Marquardt, McFarlane, Mickelson, Mittage, Montgomery, A. Morris, Norman, Padovan, Peach, Platt, Potts, Roehll, Rogers, Rolfe, Roth, Schmitt, Schreiber. Schwartz, Shimp, Silberhorn, Skelly, Sliwa, Smith, Smithson, Spale, Sparr, J. Stewart, Struck, Stumpf, Tetzlaff, Turner, Werthwein, Yanor.

Delegates not voting (36): Armer, Beck, Beezhold, Bower, Carey, Dougherty, Erickson, Funk, Gale, Hartman, Hunsaker, Keitzman, Kozicky, Lymenstull, Martin, McAllister, Mills, R. Morris, Nix, Noe, Penberthy, Pientka, Reardanz, Romano, Siegner, Spada, Spaniol, L. Stewart, Trimble, Veugeler, Walker, Walters, Weirich, White, Yacalavitch, Young. 


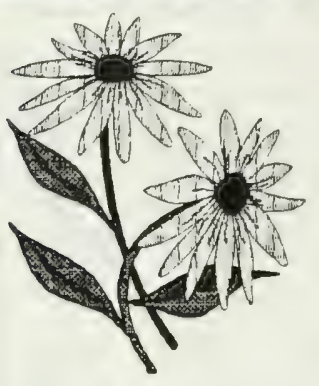

LM-5 VOTING Delegates in favor (100): Adelmann, Aitken, Baker, Bamberger, Barkley, Beck, Becker, Beezhold, Bishop, Black, Bower, Brueckner, Buenting, Bullard, Bunt, Byrns, Caffee, Campbell, Carev, Caveny, Coates, Crawford, Desulis, Dickey, Dirksen, Eichelkraut, Eyre, Falco, Gabriel, Gale, Garner, Graeff, Gross, Gruber, Guthrie, Haertel, Hagan, Hamberg, Hambly, Harney, Hartman, Hooser, Hunsaker, Jacobs, Jessen, Johnson, Jorstad, Keitzman, Kielsmeier, Konsis, Kozicky, Kutska, Lamb, Lehman, Ludwig, Lymenstull, Marquardt, McAllister, McFarlane, Mickelson, Mittage, Montgomery, R. Morris, A. Morris, Nix, Norman, Padovan, Peach, Pientka, Platt, Potts, Roehll, Rogers, Rolfe, Romano, Roth, Schmit, Schreiber, Schwartz, Shimp, Silberhorn, Skelly, Sliwa, Smith, Smithson, Spada, Spale, Spaniol, Sparr, J. Stewart, Struck, Stumpf, Tetzlaff, Trimble, Turner, Walker, Walters, Werthwein, Yanor, Young.

Delegates not voting (17): Armer, Deneen, Dougherty, Erickson, Funk, Lechner, Martin, Mills, Noe, Penberthy, Reardanz, Siegner, L. Stewart, Veugeler, Weirich, White, Yacalavitch.

\section{PRIVATE PRODUCTION AND USE OF NATIVE SEED, PLANT AND TREE MATERIALS (LM-5)}

\author{
Recommendation: Increase the use of native seeds, plants \\ and trees on public projects.
}

1. The Department of Conservation shall contact other state agencies (Transportation, Agriculture, Mine Reclamation and University of Illinois Extension Service) to develop uniform guidelines on the use of native plant materials on public projects within the state. This document should list those species, cultivars and varieties that are suitable for use in the various regions of the state. A committee shall be formed from representatives of the above units of state governments plus representatives from U.S. Department of Agriculture's Soil Conservation Service, non-governmental organizations such as The Nature Conservancy, Pheasants Forever, Quail Unlimited, The Illinois Nurserymen's Association and Illinois Landscape Contractor's Association or other knowledgeable individuals or groups.

2. Create a cooperative program for private and public landowners and the nursery industry to produce native seed, plant and tree material to supplement the recognized shortage of material for habitat restoration participants. This cooperative program is to include providing technical assistance, education and information transfer and the establishment of a communication network for growers and users to exchange information.

\section{IDOC RESPONSE:}

Guidelines do exist for use of native plant materials on public projects. The Department has an agreement with the Illinois Department of Transportation to plant native species along roadways. Wher providing technical assistance to private property owners, planting native species is encouraged.

Currently, the Department provides technical assistance to other nursery operators, when requested. A manual on growing and cleaning seeds is available upon request and tours can be arranged at each state nursery site. 


\section{LAND MANA GEMENT COMMUTTEE}

\section{HABITAT AND OUTDOOR RECREATION ACQUISITION (LM-9)}

Recommendation: The State of Illinois shall protect and enhance biodiversity and provide more outdoor recreational opportunities for its citizens. Legislation should be enacted to:

1. Establish habitat acquisition as a high priority for the Department of Conservation for the coming decades.

2. Direct the Department to acquire habitat with all deliberate speed.

3. Appropriate funds sufficient to acquire public habitat from willing sellers at an annual rate of about two-tenths of one percent of the land area of the state until sufficient lands are required to meet user need. These acquisitions are to be apportioned among a variety of recreation and conservation objectives according to the natural features and potentials of the land acquired, with ecological conservation as the primary objective.

\section{IDOC RESPONSE:}

The Department continues to support this recommendation. Additional headcount for implementing this recommendation is included in Conservation 2000.

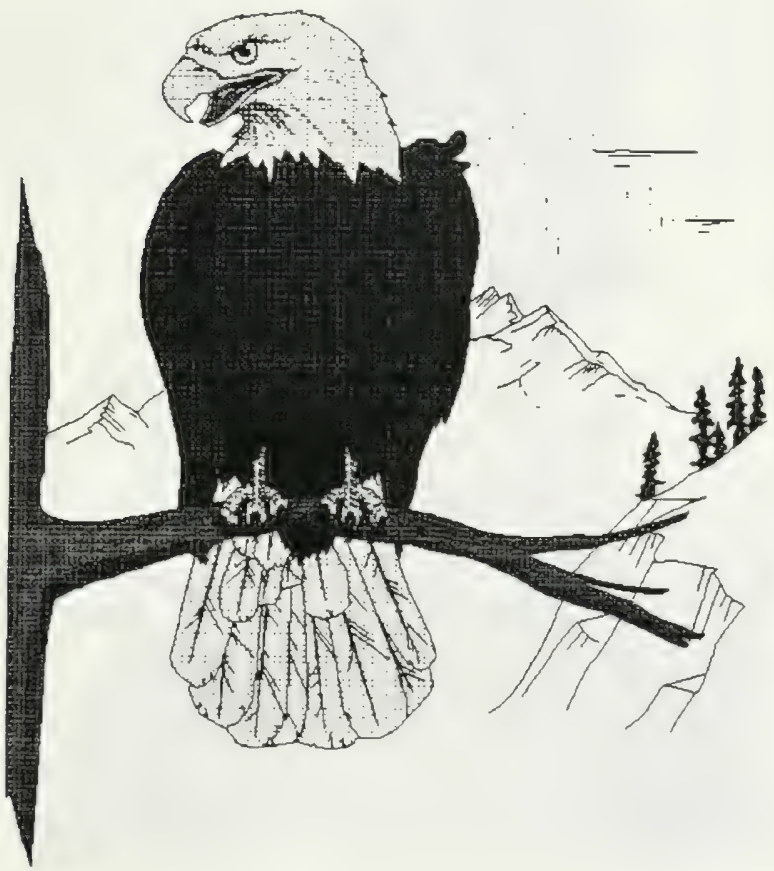

\section{LM-9 VOTING}

Delegates in favor $(81)$ :

Adelmann, Aitken, Baker,

Bamberger, Barkley, Beck,

Becker, Beezhold, Bishop,

Black, Brueckner, Bullard,

Bunt, Byrns, Caffee, Camp-

bell, Carey, Coates, Craw-

ford, Deneen, Dickey,

Eichelkraut, Eyre, Falco,

Gabriel, Garner, Graeff,

Gross, Gruber, Guthrie,

Haertel, Hamberg, Hambly,

Harney, Hooser, Hunsaker,

Jacobs, Jessen, Johnson, Jor-

stad, Kielsmeier, Konsis, Kut-

ska, Lamb, Lechner, Lehman,

Ludwig, Marquardt,

McFarlane, Mickelson, Mittage, Montgomery, A. Morris, Nix, Norman, Peach, Platt, Potts, Roehll, Romano, Roth, Schmitt, Schreiber, Schwartz, Shimp, Silberhorn, Skelly, Sliwa, Smithson, Spale, Sparr, J. Stewart, Struck, Stumpf, Tetzlaff, Trimble, Turner, Walker, Werthwein, White, Young.

Delegates not voting (36): Armer, Bower, Buenting, Caveny, Desulis, Dirksen, Dougherty, Erickson, Funk, Gale, Hagan, Hartman, Keitzman, Kozicky, Lymenstull, Martin, McAllister, Mills, R. Morris, Noe, Padovan, Penberthy, Pientka, Reardanz, Rogers, Rolfe, Siegner, Smith, Spada, Spaniol, L. Stewart, Veugeler, Walters, Weirich, Yacalavitch, Yanor. 


\section{PI-1 VOTING}

Delegates in favor (108):

Adelmann, Aitken, Armer, Baker, Bamberger, Barkley, Beck, Becker, Beezhold, Bishop, Black, Bower, Brueckner, Buenting, Bullard, Bunt, Byrns, Caffee, Campbell, Carey, Caveny, Coates, Crawford, Deneen, Desulis, Dickev, Dirksen, Eichelkraut, Erickson, Eyre, Falco, Funk, Gabriel, Gale, Garner, Graeff, Gross, Gruber, Guthrie, Haertel, Hagan, Hamberg, Hambly, Harney, Hartman, Hooser, Hunsaker, Jacobs, Jessen, Johnson, Jorstad, Keitzman, Kielsmeier, Konsis, Kozicky, Kutska, Lamb, Lechner, Lehman, Ludwig, Lymenstull, Marquardt, McAllister, McFarlane, Mickelson, Mittage, Montgomery, R. Morris, A. Morris, Nix, Noe, Norman, Padovan, Peach, Pientka, Platt, Potts, Reardanz, Roehll, Rogers, Rolfe, Romano, Roth, Schmitt, Schreiber, Schwartz, Shimp, Silberhorn, Skelly, Sliwa, Smith, Smithson, Spada, Spale, Spaniol, Sparr, J. Stewart, Struck, Stumpf, Tetzlaff, Trimble, Turner, Walker, Walters, Werthwein, White, Yanor, Young.

Delegates not voting (9):

Dougherty, Martin, Mills, Penberthy, Siegner, L. Stewart, Veugeler, Weirich, Yacalavitch.

\section{VOLUNTEER NETWORK (PI-1)}

Recommendation: Create a statewide volunteer network.

Identify existing and potential volunteer groups using the IDOC Conservation Congress data base. Existing IDOC volunteer programs should be expanded and promoted more effectively.

Coordinate statewide network goals with constituency groups. Volunteers, in partnership with IDOC, would manage the network at the local level based on policies created jointly by the volunteers and IDOC.

Encourage and train staff to support and participate in the volunteer network.

Use volunteers to educate the public and promote natural resource issues and recreational opportunities.

\section{IDOC RESPONSE:}

Current volunteer opportunities at IDOC sites will be identified and a catalog will be developed for constituent use. Regional recognition programs will be developed. A pilot recognition day will be held in April 1995. A directory of volunteers will be published and made available.

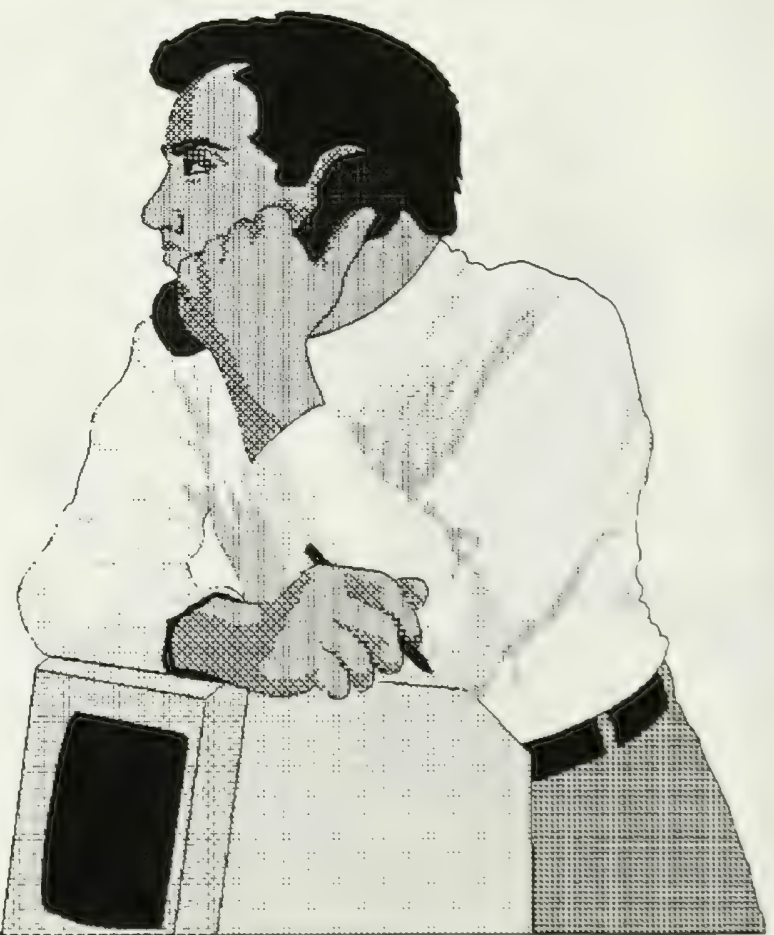




\section{PUBLIC/PRIVATE PARTNERSHIPS (PI-3)}

Recommendation: Most of the state's natural resources and wildlife habitat are on privately owned urban and rural land. Public access is often limited due to liability risk and lack of public use management.

1. Persuade legislators to further consolidate, clarify and expand liability protection to private and public parties entering into agreements or leases with the Illinois Depart ment of Conservation (IDOC) for the use of their land and water resources for recreation or conservation purposes.

2. IDOC should develop land use agreements and/or leases for use with private landowners that outline duties, responsibilities, legal obligations of State of Illinois, IDOC and land owner when used for public access.

3. Inform private and public landowmers of goals, potential uses and agreement obligations in the use of private lands for recreation or conservation uses.

4. Public users of contracted private lands for recreation or conservation purposes must be educated as to access responsibilities with possible users permits or fees.

\section{IDOC RESPONSE:}

The Department is currently exploring the opportunity for land use agreements with private landowners through a pilot program, the Outdoor Illinois Access Program. The Department and the Two Rivers Resource Conservation \& Development district are putting private landowners and outdoor recreation enthusiasts in contact with one another for the purpose of increasing outdoor recreation opportunities, including hunting, fishing, bird watching, and all other forms of recreation.

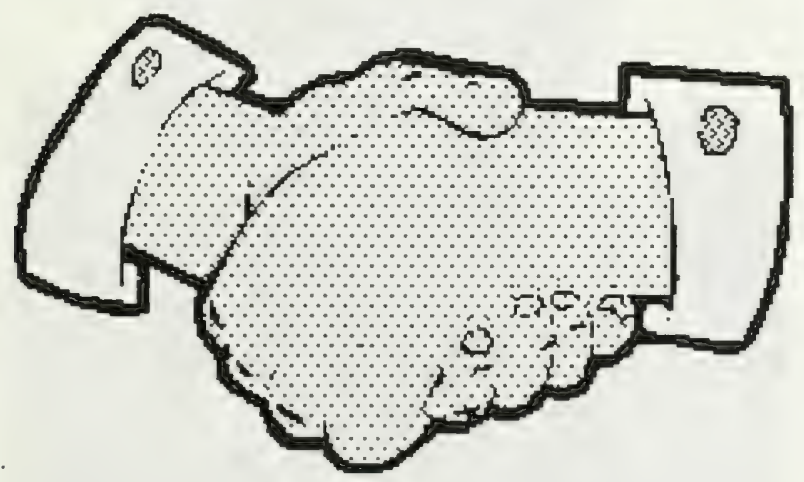

\section{PI-3 VOTING}

Delegates in favor (99): Adelmann, Aitken, Armer, Baker, Bamberger, Barkley, Beck, Becker, Beezhold, Bishop, Black, Bower, Brueckner, Buenting, Bullard, Bunt, Byrns, Campbell, Carey, Caveny, Deneen, Desulis, Dickey, Dirksen, Eichelkraut, Erickson, Evre, Falco, Funk, Gabriel, Garner, Graeff, Gross, Gruber, Guthrie, Haertel, Hagan, Hambly, Hartman, Hooser, Jacobs, Jessen, Jorstad, Keitzman, Kielsmeier, Konsis, Kozicky, Kutska, Lamb, Lechner, Lehman, Ludwig, Lymenstull, Marquardt. McAllister, McFarlane. Mickelson, Mittage Montgomery, R. Morris, A Morris, Nix, Noe, Norman, Padovan, Peach, Pientka. Platt, Potts, Reardanz. Roehll, Rogers, Rolfe, Romano, Roth, Schmitt, Schreiber, Schwartz, Silberhorn, Skelly, Sliwa, Smith, Smithson, Spada, Spale, Spaniol, Sparr, J. Stewart, Struck, Stumpf, Tetzlaff, Trimble, Turner, Walker, Walters, Werthwein, White Yanor, Young.

Delegates not voting (18): Caffee, Coates, Crawford Dougherty, Gale, Hamberg, Harney, Hunsaker, Johnson, Martin, Mills, Penberthy, Siegner, Shimp, L. Stewart, Veugeler, Weirich, Yacalavitch. 


\section{PI-4 VOTING}

Delegates in favor (93): Adelmann, Aitken, Armer, Baker, Bamberger, Barkley, Beck, Becker, Beezhold, Bishop, Black, Brueckner, Bunt, Byrns, Caffee, Campbell, Carey, Caveny, Deneen, Desulis, Dickey, Eichelkraut, Evre, Falco, Garner, Graeff, Gross, Gruber, Guthrie, Haertel, Hagan, Hamberg, Hambly, Harney, Hooser, Hunsaker, Jacobs, Jessen, Johnson, Jorstad, Keitzman, Kielsmeier, Konsis, Kozicky, Kutska, Lamb, Lechner, Lehman, Ludwig, Lymenstull, Marquardt, McAllister, Mickelson, Mittage, Montgomery, R. Morris, A. Morris, Nix, Noe, Norman, Padovan, Peach, Pientka, Platt, Potts, Reardanz, Roehll, Rogers, Rolfe, Romano, Roth, Schmitt, Schreiber, Schwartz, Shimp, Silberhorn, Skelly, Smith, Smithson, Spada, Spale, Spaniol, Sparr, Struck, Stumpf, Tetzlaff, Trimble, Turner, Walker, Walters, Werthwein, White, Young. Delegates not voting (24): Bower, Buenting, Bullard, Coates, Crawford, Dirksen, Dougherty, Erickson, Funk, Gabriel, Gale, Hartman, Martin, McFarlane, Mills, Penberthy, Siegner, Sliwa, J. Stewart, L. Stewart, Veugeler, Weirich, Yacalavitch, Yanor.

\section{STATE NATURAL RESOURCE POLICY (PI-4)}

Recommendation: The IDOC shall initiate legislation which would establish a state natural resource policy designed to sustain and enhance the state's natural resources. This policy would apply to all units of state government.

\section{IDOC RESPONSE:}

A draft policy is expected to be presented to the Natural Resources Coordinating Council in January. Director Manning will ask for further action by the Council.

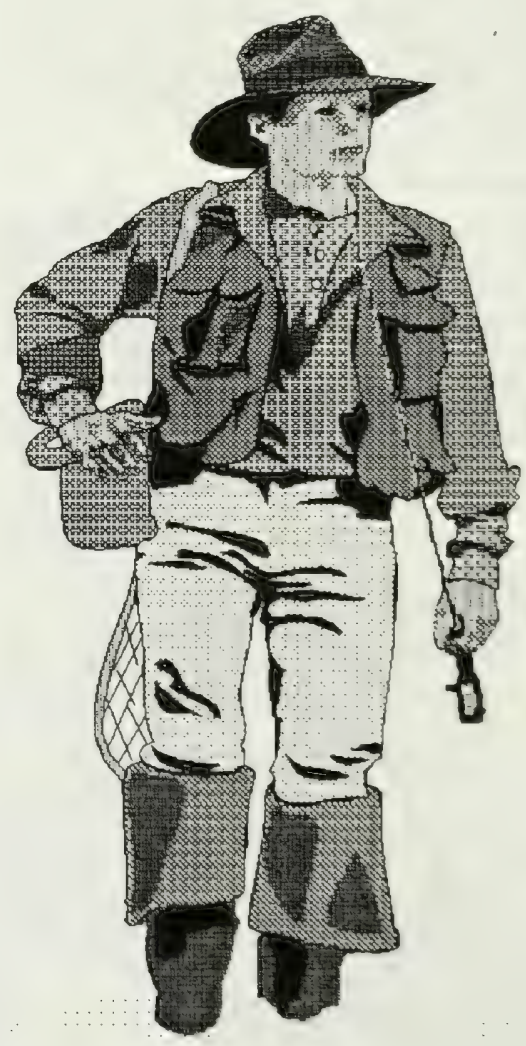




\section{EXPAND INTERN PROGRAM (PI-6)}

Recommendation: The Department of Conservation should work with the state university system to expand the intern program for recent graduates to accelerate the delivery of conservation practices on private land. Also, routine administrative tasks at the field level should be streamlined or eliminated to free biologists and foresters to work with more farmers, farm managers and follow-up on practices under way.

\section{IDOC RESPONSE:}

The Department places a large number of interns every year. The training provided to the students during these internships prepares them for a career in the natural resources field. This is an ongoing program and will continue to be expanded as opportunities arise.

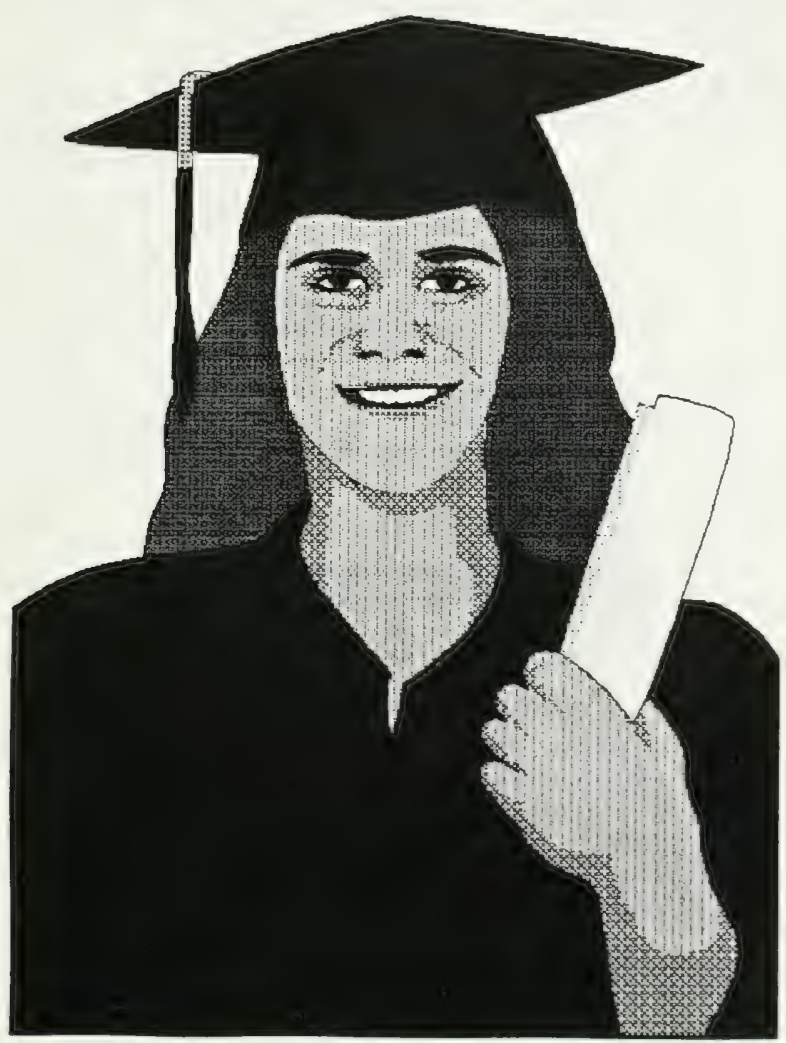

\section{PI-6 VOTING}

Delegates in favor (96):

Adelmann, Aitken, Armer, Baker, Bamberger, Barkley, Beck, Becker, Beezhold, Bishop, Black, Bower, Brueckner, Buenting, Bullard, Bunt, Byrns, Caffee, Campbell, Carey, Caveny, Coates, Crawford, Desulis. Dickey, Dirksen, Eichelkraut. Erickson, Falco, Gale, Garner. Graeff, Gross, Gruber, Guthrie, Haertel, Hagan, Hamberg, Hambly, Harney, Hartman, Hooser, Hunsaker, Jessen, Johnson, Jorstad, Keitzman, Kielsmeier, Konsis, Kozicky, Lamb, Lechner, Lehman, Ludwig, Lymenstull, Marquardt, McÁllister, McFarlane, Mickelson, Mittage, Montgomery, R. Morris, A. Morris, Nix, Noe, Norman, Padovan, Peach, Pientka, Platt, Reardanz, Roehll, Rogers, Rolfe, Romano, Roth, Schmitt, Schreiber, Schwartz, Silberhorn, Skelly, Sliwa, Smith, Smithson, Spada, Spale, Spaniol, Sparr, J. Stewart, Struck, Stumpf, Trimble, Werthwein, White, Yanor, Young.

Delegates not voting (2l): Deneen, Dougherty, Eyre, Funk, Gabriel, Jacobs, Kutska, Martin, Mills, Penberthy, Potts, Siegner, Shimp, L. Stewart, Tetzlaff, Turner, Veugeler, Walker, Walters, Weirich, Yacalavitch. 


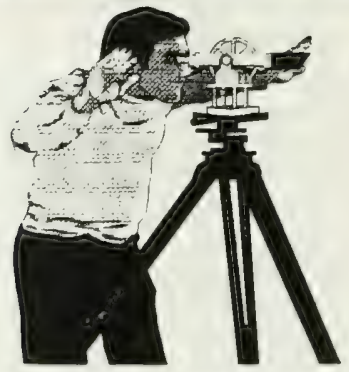

PI-8 VOTING

Delegates in favor (106):

Adelmann, Aitken, Armer, Baker, Bamberger, Barkley, Beck, Becker, Beezhold, Bishop, Black, Bower, Brueckner, Buenting, Bullard, Bunt, Byrns, Caffee, Campbell, Carey, Caveny, Coates, Deneen, Desulis, Dickey, Dirksen, Eichelkraut, Erickson, Eyre, Falco, Gabriel, Gale, Garner, Graeff, Gross, Gruber, Guthrie, Haertel, Hagan, Hamberg, Hambly, Harney, Hartman, Hooser, Hunsaker, Jacobs, Jessen, Johnson, Jorstad, Keitzman, Kielsmeier, Konsis, Kozicky, Kutska, Lamb, Lechner, Lehman, Ludwig, Lymenstull, Marquardt, McAllister, McFarlane, Mickelson, Mittage, Montgomery, R. Morris, A. Morris, Nix, Noe, Norman, Padovan, Peach, Pientka, Platt, Potts, Reardanz, Roehll, Rogers, Rolfe, Romano, Roth, Schmitt, Schreiber, Schwartz, Shimp, Silberhorn, Skelly, Sliwa, Smith, Smithson, Spada, Spale, Spaniol, Sparr, J. Stewart, Struck, Stumpf, Tetzlaff, Trimble, Turner, Walker, Walters, Werthwein, White, Yanor, Young.

Delegates not voting (11): Crawford, Dougherty, Funk, Martin, Mills, Penberthy, Siegner, L. Stewart, Veugeler, Weirich, Yacalavitch.

\section{ENVIRONMENTAL REQUIREMENTS FOR TOLLWAYS (PI-8)}

Recommendation: The IDOC Director should contact the appropriate legislators to initiate and support legislation to require the Illinois State Toll Highway Authority (IS. THA) to prepare environmental impact statements.

Require ISTHA to adequately consider the growth-related and additional infrastructure impacts of its proposed projects, within the context of existing regional and local land use plans. Require ISTHA plans to undergo a public review and comment process comparable to other state agency plans. Amend ISTHA's authorizing legislation and charter to require it to allow other modes of transportation, including bikeways and commuter train lines, within tollway rightsof-way.

\section{IDOC RESPONSE:}

Governor Edgar has said that the Tollway Authority will have to comply with environmental standards existing for IDOT projects. 


\section{TRALS \& GREDWWAY CONMTITHE}

\section{STATEWIDE GREENWAY AND TRAIL PLAN (TG-1)}

Recommendation: Establish a process to plan and coordinate statewide greenway and trail development involving the Department, other agencies, organizations and the public.

Implement the process to prepare a comprehensive statewide greenway and trail plan for Illinois. The plan should be sensitive to biological diversity and other natural resources, local concerns, landormer interests, regional geographic features and population density and to compatibility of users; and should serve as "the" plan for guiding acquisition, development and operation of these critical natural resource links and corridors. The current State Trails Plan, the Northeastern Illinois Regional Greenways Plan, the Strategic Plan for the Illinois Department of Conservation and local master plans will serve as a strong start for the Illinois Greenways Plan.

\section{IDOC RESPONSE:}

The Department has created a greenways program. In cooperation with local units of government and greenways organizations, workshops will be held around the state to stimulate local interest and action. Seed money will be provided for greenway planning in metropolitan areas.

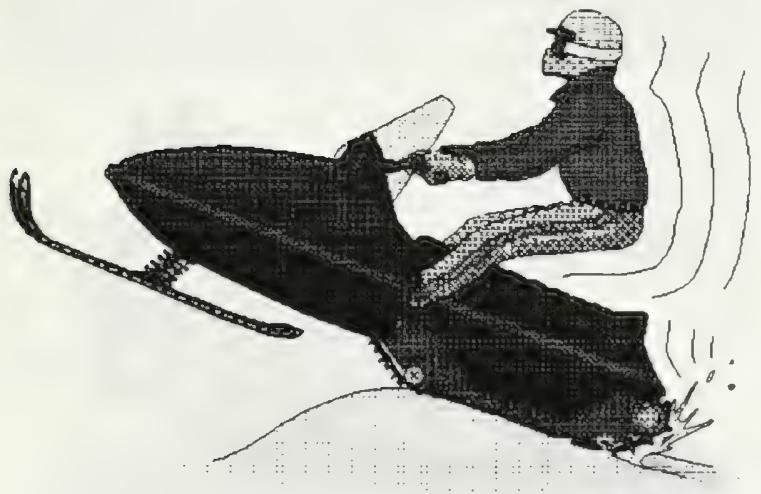

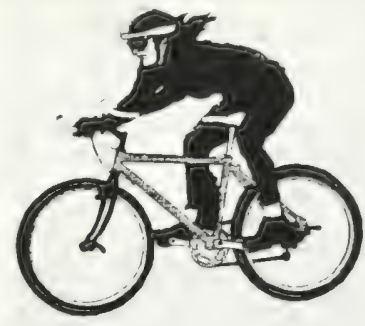

\section{TG-1 VOTING}

Delegates in favor (99):

Adelmann, Aitken, Baker, Bamberger, Barkley, Beck, Becker, Beezhold, Bishop, Bower, Brueckner, Bullard, Bunt, Byrns, Caffee, Campbell, Carey, Caveny, Coates, Crawford, Desulis, Dickey, Dirksen, Eichelkraut, Erickson, Eyre, Falco, Funk, Gabriel, Gale, Garner, Graeff, Gross, Gruber, Haertel, Hagan, Hamberg, Hambly, Harney, Hooser, Hunsaker, Jacobs, Jessen, Johnson, Jorstad, Kielsmeier, Konsis, Kozicky, Kutska, Lamb, Lechner, Lehman, Ludwig, Lymenstull, Marquardt, McAllister, McFarlane, Mickelson, Mittage, Montgomery, R. Morris, A. Morris, Nix, Noe, Norman, Padovan, Peach, Pientka, Platt, Potts, Roehll. Rogers, Rolfe, Romano, Roth, Schmit, Schreiber, Schwartz, Shimp, Silberhorn, Skelly, Sliwa, Smith, Smithson, Spada, Spale, Spaniol, Sparr, J. Stewart, Struck, Stumpf, Tetzlaff, Trimble, Turner, Walker, Werthwein, White, Yanor, Young.

Delegates not voting (18): Armer, Black, Buenting, Deneen, Dougherty, Guthrie, Hartman, Keitzman, Martin, Mills, Penberthy, Reardanz, Siegner, L. Stewart, Veugeler, Walters, Weirich, Yacalavitch. 
TG-2 VOTING

Delegates in favor (73):

Adelmann, Baker, Bamberger, Barkley, Beck, Becker, Beezhold, Bishop, Black, Brueckner, Bullard, Bunt, Byrns, Caffee, Campbell, Carev, Coates, Crawford, Dickey, Eichelkraut, Eyre, Falco, Gabriel, Gale, Garner, Gross, Gruber, Haertel, Hamberg, Hambly, Harney, Hooser, Jacobs, Jessen, Johnson, Jorstad, Kielsmeier, Kutska, Lehman, Ludwig, Marquardt, McFarlane, Mickelson, Mittage, Montgomery, A. Morris, Norman, Padovan, Peach, Platt, Roehll, Rogers, Rolfe, Roth, Schmitt, Schreiber, Schwartz, Shimp, Silberhorn, Skelly, Sliwa, Smith, Spada, Spale, Sparr, Struck, Stumpf, Tetzlaff, Turner, Werthwein, White, Yanor, Young.

Delegates not voting (44): Aitken, Armer, Bower, Buenting, Caveny, Deneen, Desulis, Dirksen, Dougherty, Erickson, Funk, Graeff, Guthrie, Hagan, Hartman, Hunsaker, Keitzman, Konsis, Kozicky, Lamb, Lechner, Lymenstull, Martin, McAllister, Mills, R. Morris, Nix, Noe, Penberthy, Pientka, Potts, Reardanz, Romano, Siegner, Smithson, Spaniol, J. Stewart, L. Stewart, Trimble, Veugeler, Walker, Walters, Weirich, Yacalavitch.

\section{ADDITIONAL PROTECTION TO PRIORITY STREAM SEGMENTS (TG-2)}

\section{Recommendation: Priority Stream Segments shall receive additional protection as follows:}

1. The Governor shall, by Executive Order, direct all state agencies (IDOC, IEPA, IDOT) to provide additional protection to Priority Stream Segments (approximately six percent of total stream miles in the state) through focused attention in the existing permit review process. Projects affecting Priority Stream Segments would receive extraordinary review and would be considered to be in especially sensitive areas. Any activity that would affect the water quality, or the physical, biological or hydrological stability of a declared Priority Stream Segment would require special permitting attention.

The IDOC shall make known this list of Priority Stream Segments to the U.S. Army Corps of Engineers to emphasize the significance of these watenvays and that special permitting attention is warranted for these streams. Emphasize that this is not intended to "write off" other stream reaches, but the exceptional quality of Priority Stream Segments elevates them to special protection, over and above the normal consideration.

The IDOC shall emphasize protection to the riparian corridors of Priority Stream Segments through its habitat acquisition priorities established in the Congress' related recommendations. Access to riparian corridors for recreation should be developed if the activities are compatible with the maintenance of the ecological integrity of the stream.

2. All rivers and streams in the state will be considered for Priority Stream Segment dassification. Those dassified as Priority Stream Segments shall meet one or more of the following criteria:

${ }^{*}$ Free-flowing in a relatively undeveloped corridor with outstanding characteristics as listed in the National Park Service 1982 Nationwide Rivers Inventory and protected by the Presidential Directive of August 1979 against federal agency actions which might foreclose

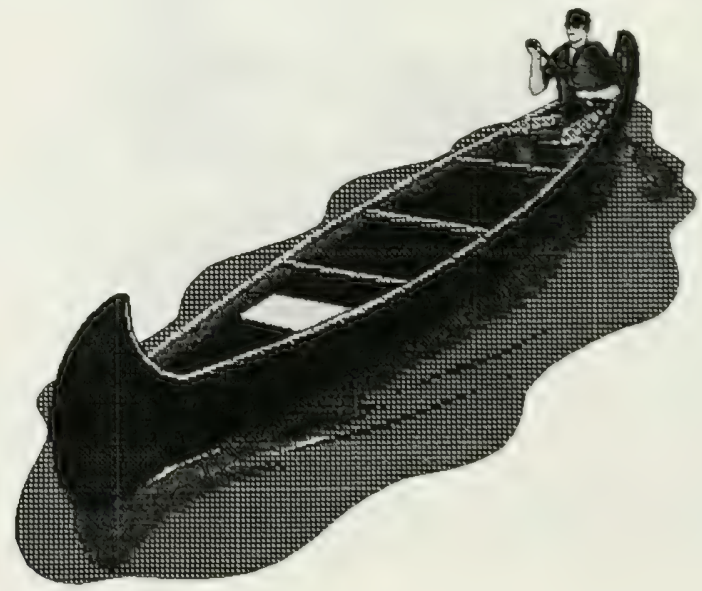


protection under the federal Wild and Scenic Rivers Act [ 16 U.S.C. 127 I et seq].

*Outstanding examples of aquatic habitat identified in the Illinois Natural Areas Inventory or covered by the Illinois Natural Area Preservation Act.

${ }^{*}$ Critical habitat for threatened or endangered species listed or proposed to be listed under the Illinois Endangered Species Protection Act or listed or proposed to be listed under the Federal Endangered Species Act.

*In the highest biotic integrity class based on a statewide rating by the Department of Conservation and Environmental Protection Agency of fish species diversity, presence of pollution intolerant fish species and low incident of undesirable fish species.

*Rivers and streams with scenic, recreational, ecological, historical or archaeological qualities of statewide significance permanently preserved as a state protected river designated by statute.

3. Priority Stream Segments and their corresponding riparian corridors should be incorporated into the IDOC strategic plan. Along with the designated segments, strategic planning for maintaining the long-term integrity of each segment should be incorporated.

4. Through legislative action, the IDOC will be the administrative agency responsible for the designation of Priority Stream Segments.

\section{IDOC RESPONSE:}

A State Protected Streams work group with representatives from Conservation, Division of Water Resources, EPA, Agriculture, Illinois Natural History Survey, Illinois State Water Survey, Illinois Nature Preserves Commission, Mines and Minerals and the Illinois Pollution Control Board has been organized to review the legal protections currently afforded streams through state and federal law. The objective is to identify the major weaknesses where threats to the outstanding values of streams, particularly those listed as high priority st reams, cannot be prevented under current law. The work group will evaluate the possibility of a joint permit system to collectively unify federal and state regulatory efforts as well as the need for legislation to provide additional legal protection.

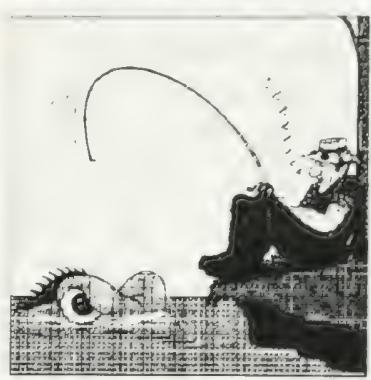

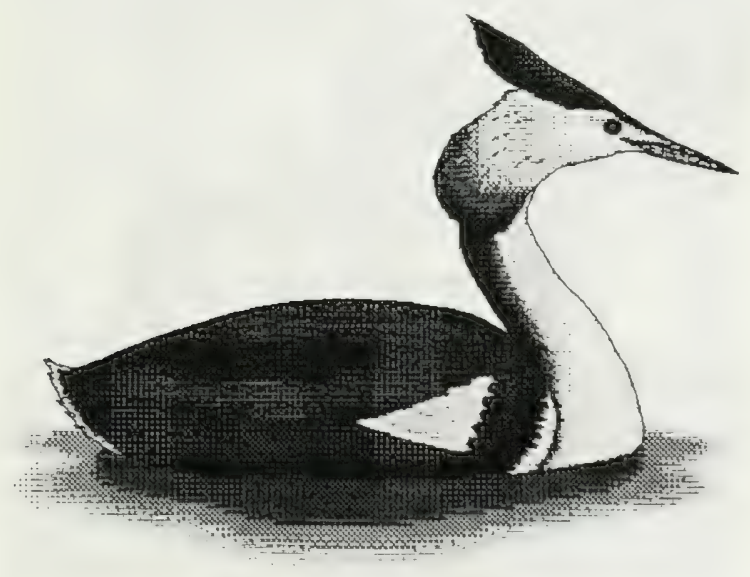




\section{TG-3 VOTING}

Delegates in favor (106):

Adelmann, Aitken, Armer, Baker, Bamberger, Barkley, Beck, Becker, Beezhold, Bishop, Black, Bower, Brueckner, Buenting, Bullard, Bunt, Byrns, Caffee, Campbell, Carey, Caveny, Coates, Crawford, Deneen, Desulis, Dickey, Dirksen, Eichelkraut, Erickson, Eyre, Falco, Funk, Gabriel, Gale, Garner, Graeff, Gross, Gruber, Guthrie, Haertel, Hagan, Hamberg, Hambly, Harney, Hartman, Hooser, Hunsaker, Jacobs, Jessen, Johnson, Jorstad, Keitzman, Kielsmeier, Konsis, Kozicly, Kutska, Lamb, Lechner, Lehman, Ludwig, Lymenstull, Marquardt, McAllister, McFarlane, Mickelson, Mittage, Montgomery, A. Morris, Nix, Noe, Norman, Padovan, Peach, Pientka, Platt, Potts, Reardanz, Roehll, Rogers, Rolfe, Romano, Roth, Schmitt, Schreiber, Schwartz, Shimp, Silberhorn, Skelly, Sliwa, Smith, Smithson, Spada, Spale, Spaniol, Sparr, J. Stewart, Struck, Stumpf, Tetzlaff, Trimble, Turner, Walker, Walters, Werthwein, Yanor, Young.

Delegates not voting (11): Dougherty, Martin, Mills, R. Morris, Penberthy, Siegner, L. Stewart, Veugeler, Weirich, White, Yacalavitch.

\section{STATEWIDE PLAN FOR RESTORATION OF STREAM CORRIDORS (TG-3)}

Recommendation: Prepare a statewide strategic plan for the improvement of stream corridors and establish an educational outreach program.

The improvement of water quality is the primary goal. Benefits include: flood management, cropland protection, wildlife habitat and greenways. The Department of Conservation, as the lead agency, would coordinate with the IEPA to designate those watersheds with poor water quality. The IDOC would work with IDOA and local soil and water conservation districts to help landowners establish and enhance riparian areas through education and effective conservation practices with incentives such as cost-sharing programs, management agreements and other innovative techniques.

\section{IDOC RESPONSE:}

This is included in Conservation 2000.

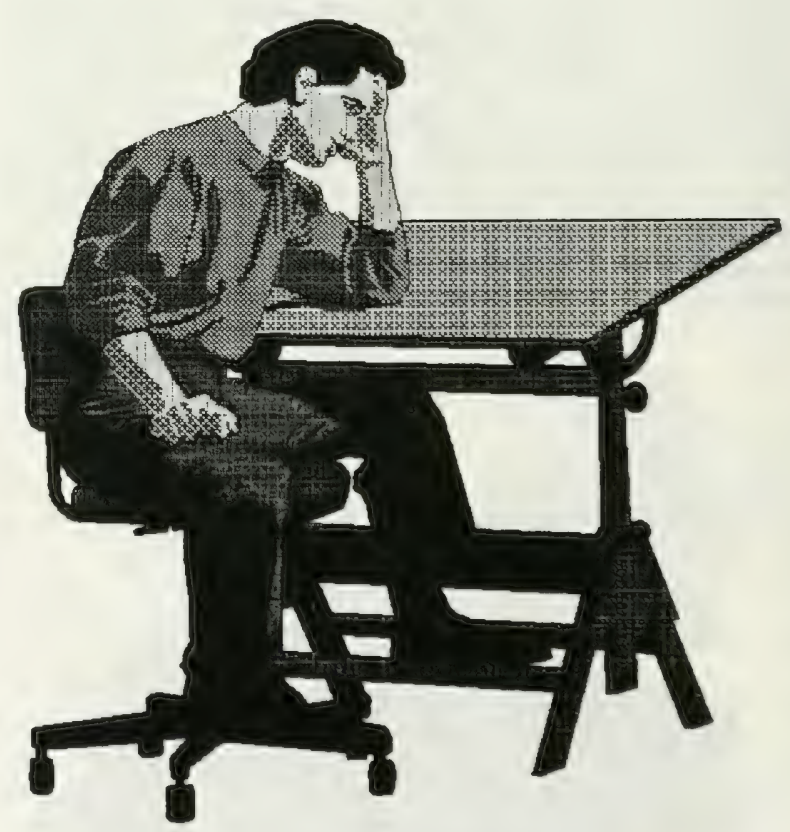




\section{TRATLS E GRDEWWAS CONMUTWE}

\section{NO DISCHARGE ZONES IN ILLINOIS (TG-6)}

Recommendation: The Department of Conservation should use the provisions of the Clean Vessel Act of 1992 to provide boaters with adequate sewage disposal systems and ultimately have USEPA declare all water in Illinois as "no discharge zones."

\section{IDOC RESPONSE:}

A federal grant program administered by the Department will be available in IY96 to implement this recommendation. The Department has contracted with the University of Illinois to complete a suney of coastal waters to determine needs for pumpout stations and to develop a plan to address those needs and set priorities. The survey results and plan are completed. With few exceptions (must own property or have a lease with at least five years remaining which does not have a termination at will clause), any operator of a boat access area in Illinois is eligible to apply for grant money to construct pumpout stations. Deadline to apply for the grant was Feb. 15, 1995, with approval scheduled for November or December 1995. No const ruction or expenditure of money can occur prior to final approval of the grant. After construction is complete, 75 percent of allowable costs will be reimbursed to the boat access area.

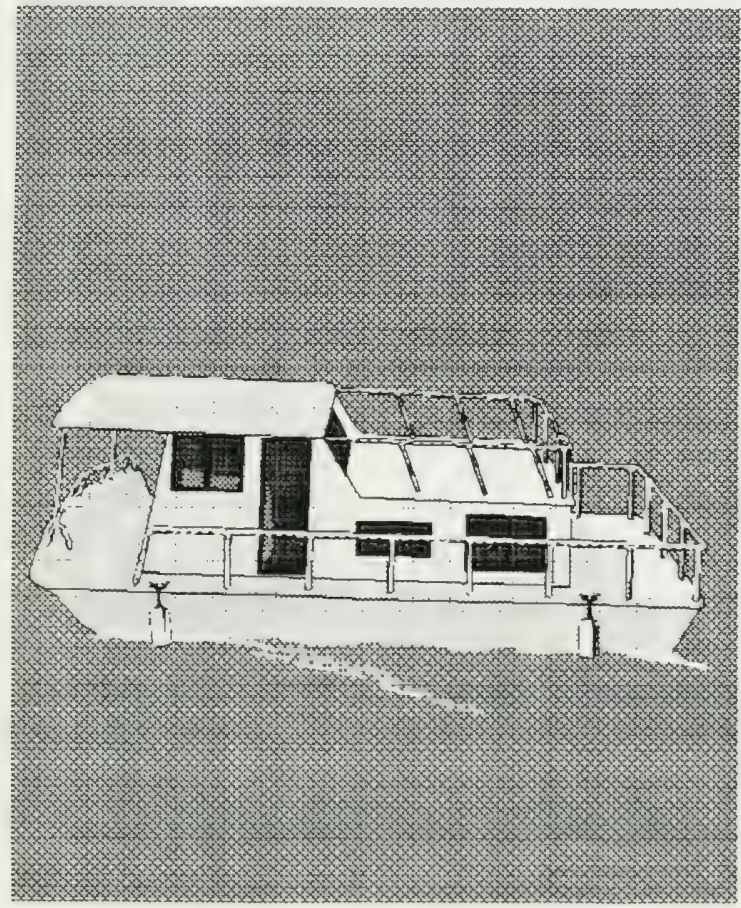

\section{TG-6 VOTING}

Delegates in favor $(100)$ : Adelmann, Aitken, Armer, Baker, Bamberger, Barklev. Beck, Becker, Beezhold, Bishop, Black, Bower, Brueckner, Bullard, Bunt, Byrns, Caffee, Campbell, Carey, Caveny, Coates, Crawford, Deneen, Desulis, Dickey, Dirksen, Eichelkraut, Erickson, Eyre, Falco, Gabriel, Garner, Graeff, Gross, Gruber, Guthrie, Haertel, Hagan, Hamberg, Hambly, Harney, Hooser, Hunsaker, Jacobs, Jessen, Johnson, Jorstad, Keitzman, Konsis, Kozicky, Kutska, Lamb, Lechner, Lehman, Ludwig, Marquardt, McFarlane, Mickelson, Mittage, Montgomery, R. Morris, A. Morris, Nix, Noe, Norman, Padovan, Peach, Pientka, Platt, Potts, Reardanz, Roehll, Rogers, Rolfe, Romano, Roth, Schmitt, Schreiber, Schwartz, Shimp, Silberhorn, Skelly, Sliwa, Smith, Smithson, Spale, Spaniol, Sparr, J. Stervart, Struck, Stumpf, Tetzlaff, Trimble, Turner, Walker, Walters, Werthwein, White, Yanor, Young.

Delegates not voting (17): Buenting, Dougherty, Funk, Gale, Hartman, Kielsmeier, Lymenstull, Martin, McAllister, Mills, Penberthy, Siegner, Spada, L. Stewart, Veugeler, Weirich, Yacalavitch. 


\section{EID}

\section{ED-1 VOTING}

Delegates in favor (107):

Adelmann, Aitken, Armer, Baker, Bamberger, Barkley, Beck, Becker, Beezhold, Bishop, Black, Bower, Brueckner, Buenting, Bullard, Bunt, Byrns, Caffee, Campbell, Carey, Caveny, Coates, Crawford, Deneen, Desulis, Dickey, Dirksen, Eichelkraut, Erickson, Eyre, Falco, Funk, Gabriel, Gale, Garner, Graeff, Gross, Gruber, Guthrie, Haertel, Hagan, Hamberg, Hambly, Harney, Hartman, Hooser, Hunsaker, Jacobs, Jessen, Johnson, Keitzman, Kielsmeier, Konsis, Kozicky, Kutska, Lamb, Lechner, Lehman, Ludwig, Lymenstull, Marquardt, McAllister, McFarlane, Mickelson, Mittage, Montgomery, R. Morris, A. Morris, Nix, Noe, Norman, Padovan, Peach, Pientka, Platt, Potts, Reardanz, Roehll, Rogers, Rolfe, Romano, Roth, Schmitt, Schreiber, Schwartz, Shimp, Silberhorn, Skelly, Sliwa, Smith, Smithson, Spada, Spale, Spaniol, Sparr, J. Stewart, Struck, Stumpf, Tetzlaff, Trimble, Turner, Walker, Walters, Werthwein, White, Yanor, Young.

Delegates not voting (10): Dougherty, Jorstad, Martin, Mills, Penberthy, Siegner, L. Stewart, Veugeler, Weirich, Yacalavitch.

\section{DIVISION OF EDUCATION (ED-1)}

Recommendation: The Illinois Department of Conservation should create a Division of Education to focus atten. tion on the importance of conservation education and to consolidate and better coordinate the educational efforts taking place within the Department.

\section{IDOC RESPONSE:}

A Division of Education will be created by the beginning of FY96 (July 1, 1995). All Education recommendations will be analyzed by the division staff and incorporated, when possible, into the objectives of the division.

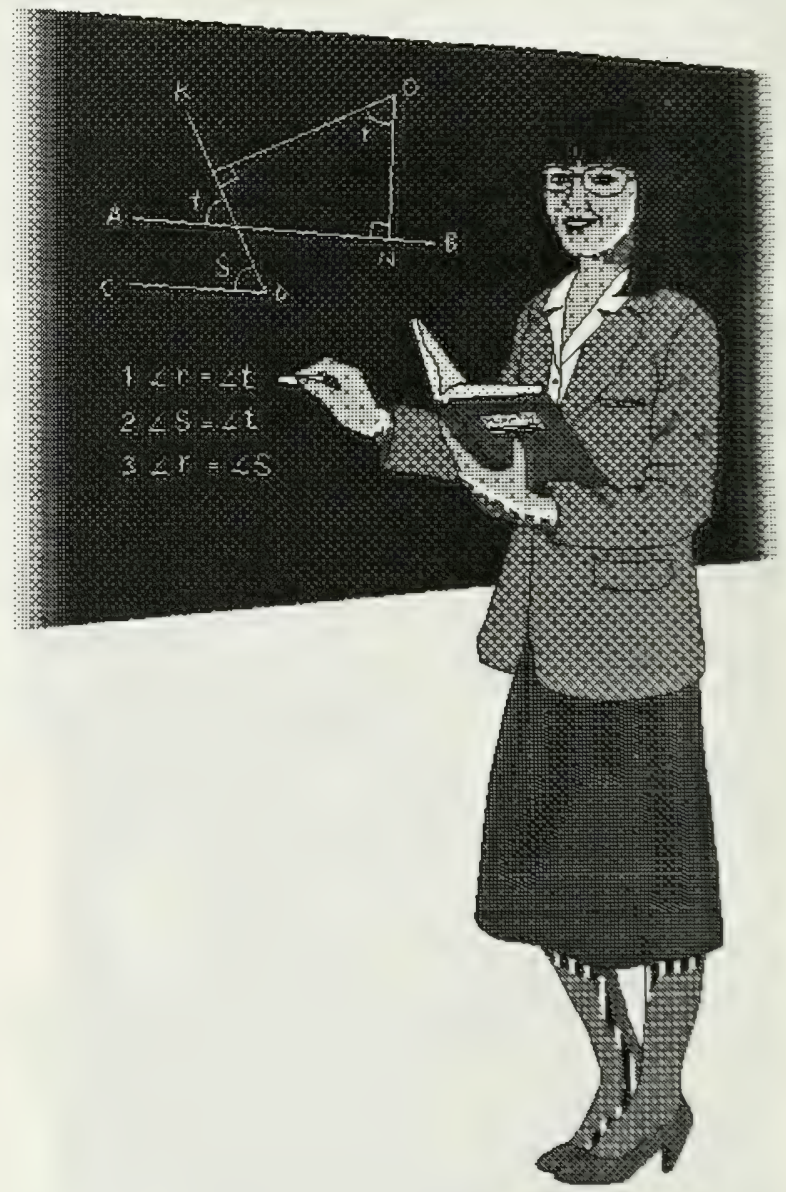




\section{REGIONAL CONSERVATION SPECIALISTS (ED-2)}

Recommendation: IDOC should employ, one at a time as funds become available, at least six Conservation Education Specialists, one for each of the five regions and one for Cook County.

The Education Specialists would serve as liaisons between the regional staff, volunteers, public and private education agencies and organizations and public interest groups.

Positions would be added, one by one, as funding becomes available to support the new staff and their operations. Any surplus funds, after the initial six Conservation Education Specialists are hired, shall be used for the development of new materials. Additional outreach efforts and further staff will be added as warranted.

A source of funding for this Conservation Education Program could be from a specific, dedicated percentage of IDOC's overall budget and/or from a specific, dedicated percentage of all dedicated funding for IDOC programs, existing and future.

\section{IDOC RESPONSE:}

Same as response to ED-1.

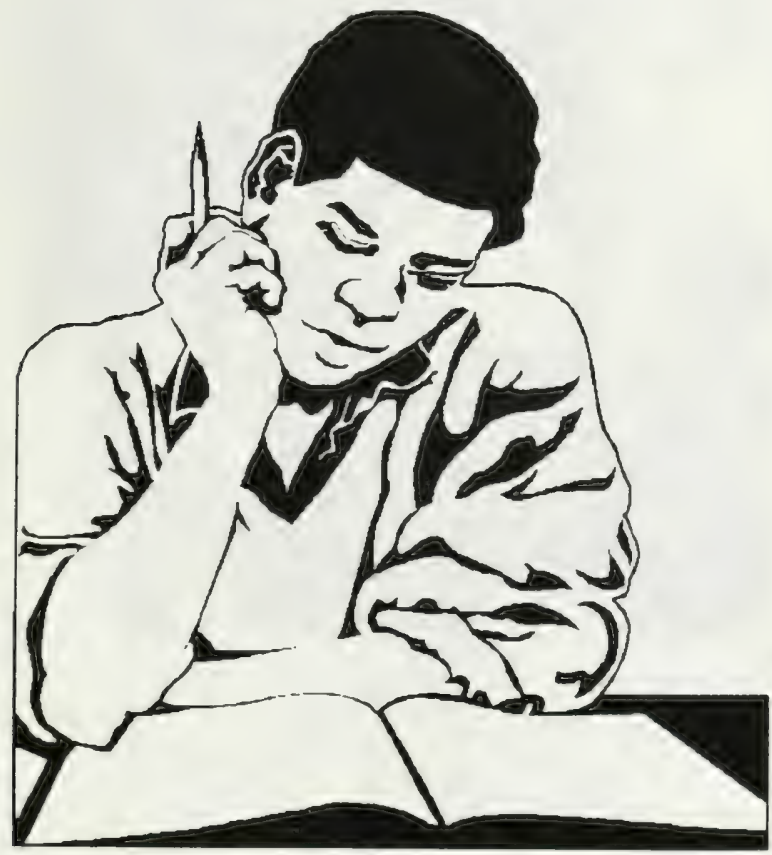

\section{ED-2 VOTING}

Delegates in favor (102):

Adelmann, Aitken, Armer, Baker, Bamberger, Barkley, Beck, Becker, Beezhold, Bishop, Black, Bower, Brueckner, Buenting, Bullard, Bunt, Byrns, Caffee, Campbell, Carey, Caveny. Coates, Crawford, Deneen, Desulis, Dickey, Dirksen, Eichelkraut, Erickson, Eyre Falco, Funk, Gabriel, Gale. Garner, Graeff, Gross, Gruber, Guthrie, Haertel, Hagan, Hamberg, Hambly, Harney, Hartman, Hooser, Hunsaker, Jacobs, Johnson, Jorstad, Kielsmeier, Konsis, Kozicky, Lamb, Lechner, Ludwig, Lymenstull, Marquardt, McAllister, McFarlane, Mickelson, Mittage, Montgomery, R. Morris, A. Morris, Nix, Noe, Norman, Padovan, Peach, Pientka, Platt, Potts, Reardanz, Rogers, Rolfe, Romano, Roth, Schmitt, Schreiber, Schwartz, Silberhorn, Skelly, Sliwa, Smith, Smithson, Spada, Spale, Spaniol, Sparr, J. Stewart, Struck, Stumpf, Tetzlaff, Trimble, Turner, Walker, Walters, Werthwein, White, Yanor, Young.

Delegates not voting (15): Dougherty, Jessen, Keitzman, Kutska, Lehman, Martin, Mills, Penberthy, Roehll, Siegner, Shimp, L. Stewart, Veugeler, Weirich, Yacalavitch. 


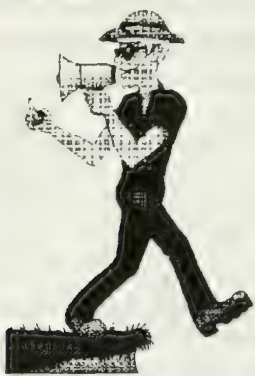

\section{ED-3 VOTING}

Delegates in favor (97):

Adelmann, Aitken, Armer, Baker, Bamberger, Barklev, Beck, Becker, Beezhold, Bishop, Bower, Buenting, Bullard, Byrns, Caffee, Campbell, Carey, Caveny, Coates, Deneen, Desulis, Dickey, Dirksen, Eichelkraut, Erickson, Eyre, Falco, Gale, Garner, Graeff, Gross, Gruber, Haertel, Hagan, Hamberg, Hambly, Harney, Hartman, Hooser, Hunsaker, Jacobs, Jessen, Johnson, Jorstad, Keitzman, Kielsmeier, Konsis, Kozicky, Kutska, Lamb, Lechner, Lehman, Ludwig, Lymenstull, Marquardt, McAllister, McFarlane, Mickelson, Mittage, Montgomery, R. Morris, A. Morris, Nix, Noe, Norman, Padovan, Peach, Pientka, Platt, Potts, Reardanz, Roehll, Rogers, Rolfe, Romano, Roth, Schmitt, Schreiber, Schwartz, Silberhorn, Skelly, Sliwa, Smith, Smithson, Spada, Spale, Spaniol, Sparr, Struck, Stumpf, Trimble, Walker, Walters, Werthwein, White, Yanor, Young.

Delegates not voting (20): Black, Brueckner, Bunt, Crawford, Dougherty, Funk, Gabriel, Guthrie, Martin, Mills, Penberthy, Siegner, Shimp, J. Stewart, L. St ewart, Tetzlaff, Turner, Veugeler, Weirich, Yacalavitch.

\section{HIGHER PRIORITY ON INTERPRETIVE EDUCATION AT SPECIFIC SITES (ED-3)}

Recommendation: The Department of Conservation should place a higher priority on interpretive education at specific sites, as an integral part of the site management.

The Department needs to survey the needs and desires of its local site base and incorporate the involvement of local educational institutions, constituency groups and local area volunteers. Methods of implementation would depend on site-specific circumstances.

\section{IDOC RESPONSE:}

Same as response to ED-1.

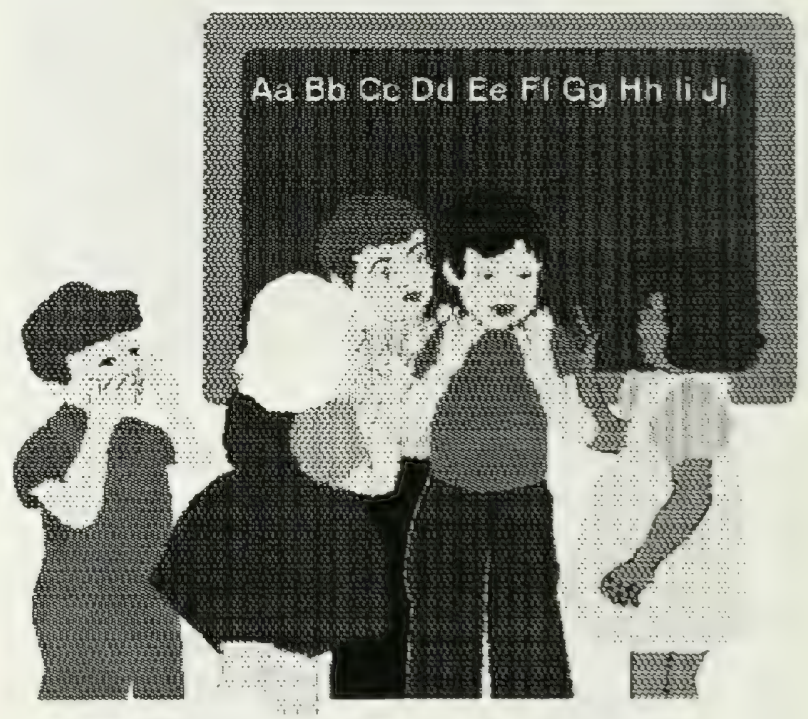




\section{AVAILABILITY OF INFORMATION TO THE PUBLIC (ED-4)}

Recommendation: To increase the availability of information to the public, and educational groups in particular, the Department of Conservation should strengthen and publicize its developing central information clearing. house for conservation and environmental education.

There is an abundance of good conservation education materials available. Because these materials have been produced by a variety of sources, people needing this information, educators in particular, have difficulty learning about the material. The fewer directions interested persons have to look to gather conservation education materials the better they can educate the public. The 1993 Conservation Education Catalog is a good beginning, but many educators, as well as the general public, are not aware of its availability.

Easier availability of IDOC materials could be accomplished by further development of a clearinghouse. However, the IDOC should go beyond that by also providing a directory of contact persons in other agencies, industries, environmental groups and in other states. This could take the form of a computer database accessible through public libraries, schools and the Internet System available to universities. Many volunteers statewide have an abundance of information they are willing to share as speakers or teachers if they were called upon. Unfortunately, teachers and group leaders needing these people's talents and knowledge do not know who they are. A Conservation Information Hotline would make more conservation materials and speakers available to more people, much easier and quicker than currently possible.

\section{IDOC RESPONSE:}

Same as response to ED-I.

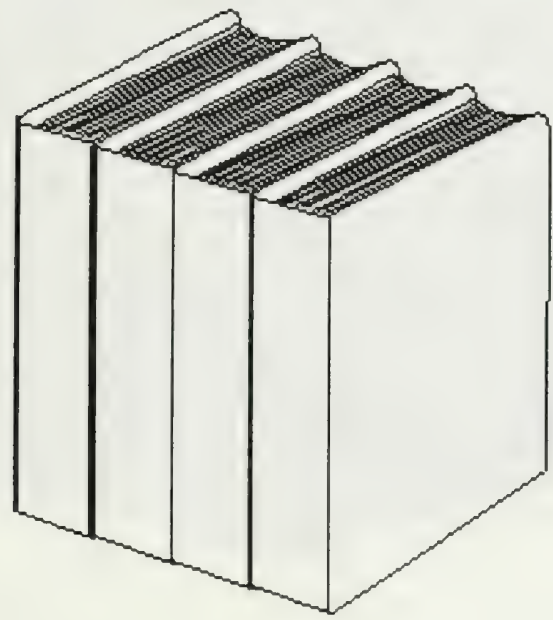

\section{ED-4 VOTING}

Delegates in favor (99):

Adelmann, Armer, Baker. Bamberger, Barkley, Beck, Beezhold, Bishop, Black, Bower, Brueckner, Buenting, Bullard, Bunt, Byrns, Caffee, Campbell, Caveny, Coates, Deneen, Desulis, Dickev, Dirksen, Eichelkraut, Erickson, Eyre, Falco, Gale, Garner, Graeff, Gross, Gruber, Guthrie, Haertel, Hagan, Hamberg, Hambly, Harney, Hooser, Hunsaker, Jacobs, Jessen, Johnson, Jorstad, Keitzman, Kielsmeier, Konsis, Kozicky, Kutska, Lamb, Lechner, Lehman, Ludwig, Lymenstull, Marquardt. McFarlane, Mickelson, Mittage, Montgomery, R. Morris, A. Morris, Nix, Noe, Norman, Peach, Pientka, Platt, Potts, Reardanz, Roehll, Rogers, Rolfe, Romano, Roth, Schmitt, Schreiber, Schwartz, Shimp, Silberhorn, Skelly, Sliwa, Smith, Smithson, Spada, Spale, Spaniol, Sparr, J. Stewart, Struck, Stumpf, Tetzlaff, Trimble, Turner, Walker, Walters, Werthwein, White, Yanor, Young.

Delegates not voting (18): Aitken, Becker, Carey, Crawford, Dougherty, Funk, Gabriel, Hartman, Martin, McAllister, Mills, Padovan, Penberthy, Siegner, L. Stewart, Veugeler, Weirich, Yacalavitch. 


\section{FUNDING COMMUTHED}

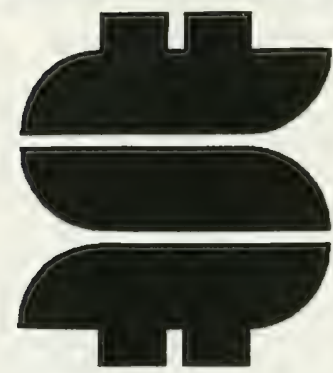

\section{F-1/2 VOTING}

Delegates in favor (98):

Adelmann, Aitken, Baker, Bamberger, Barkley, Beck, Becker, Beezhold, Bishop, Black, Brueckner, Buenting, Bullard, Bunt, Byrns, Caffee, Campbell, Carey, Coates, Crawford, Deneen, Desulis, Dickey, Dirksen, Eichelkraut, Eyre, Falco, Funk, Gabriel, Gale, Garner, Graeff, Gross, Gruber, Guthrie, Haertel, Hagan, Hamberg, Hambly, Harney, Hooser, Hunsaker, Jacobs, Jessen, Johnson, Jorstad, Keitzman, Kielsmeier, Konsis, Kutska, Lamb, Lechner, Lehman, Ludwig, Lymenstull, Marquardt, McFarlane, Mickelson, Mittage, Montgomery, R. Morris, A. Morris, Nix, Noe, Norman, Padovan, Peach, Pientka, Platt, Potts, Reardanz, Roehll, Rogers, Rolfe, Romano, Roth, Schmitt, Schreiber, Schwartz, Shimp, Silberhorn, Skelly, Sliwa, Smith, Smithson, Spada, Spale, Sparr, J. Stewart, Struck, Stumpf, Tetzlaff, Trimble, Turner, Werthwein, White, Yanor, Young. Delegates not voting (19): Armer, Bower, Caveny, Dougherty, Erickson, Hartman, Kozicly, Martin, McAllister, Mills, Penberthy, Siegner, Spaniol, L. Stewart, Veugeler, Walker, Walters, Weirich, Yacalavitch.

\section{CONSERVE OLLINOIS PROGRAM (F-1/2)}

Recommendation: Increase the state sales tax by $1 / 8$ th of 1 percent. Revenue generated from the sales tax increase of $1 / 8$ th of 1 percent will be dedicated as follows:

I. 50 percent of the proceeds will be dedicated to the Conserve Illinois Program Fund.

Monies placed in this fund will be used to meet unaddressed critical needs for park and natural areas acquisition and development at both the state and local level; stewardship and conservation easements; and identification systems and restoration programs for vacant post-industrial land. Proceeds may be used to retire bonds issued for these programs.

2. 50 percent of the proceeds will be dedicated to a Conservation Trust Fund.

Monies placed in the fund would be in addition to appropriations from dedicated revenue sources, but in lieu of general revenue funds annually provided to the Department. The intent of the trust fund would be threefold: to place the Department on a sound fiscal basis for the foreseeable future; to minimize the necessity for the IDOC to submit numerous proposals for legislative action to generate additional funding for existing and/or new programs; and to ensure there are adequate staff and funding to properly manage the state's natural resources for the benefit and enjoyment of Illinois citizens, now and in the future.

\section{IDOC RESPONSE:}

The Conservation Congress II Funding Committee was charged with considering revenue sources that could be used to implement the other Congress recommendations. During the Congress, at the request of the Funding Committee, the Department estimated the cost to implement all recommendations passed by the five non-funding committees, based upon the information submitted with the recommendations and Department estimates. The estimate of $\$ 108$ million in this report reflects only those recommendations that were passed by the Assembly of Delegates and includes one-time and recurring costs.

The funding recommendations that were passed by the Assemblv, estimated to generate a total of $\$ 158$ million annually based upon information provided in the recommendations, are: an increase of $1 / 8$ th of 1 percent in the state sales tax, which also was a Conservation Congress 1 funding recommendation (F-1/2); a watenvay fee that applies to commercial goods ( $\$ .10 /$ ton) and to passengers ( $\$ 1 /$ head) at the loading or unloading dock for all Illinois river or lake terminals $(\mathrm{F}-5)$; a non-recycled paper tax $(\mathrm{F}-7)$; and a video tape rental tax (F-8).

All funding recommendations have been transmitted to the Governor's Office.

The Governor has indicated that the increase in the state sales tax (F-1/2) would not be endorsed at this time. 


\section{ILLINOIS WATERWAY FEE (F-5)}

Recommendation: Establish the Illinois Waterway Fee to be placed on commercial goods (10 cents per ton) and passengers (\$1 per head) at the loading or unloading point at all docking tie-ups at lake or river terminals in the state.

These funds to be targeted at efforts to bolster tourism and recreational opportunities through funding overall environmental protection and restoration initiatives.

\section{IDOC RESPONSE:}

Same as response to $\mathrm{F}-1 / 2$.

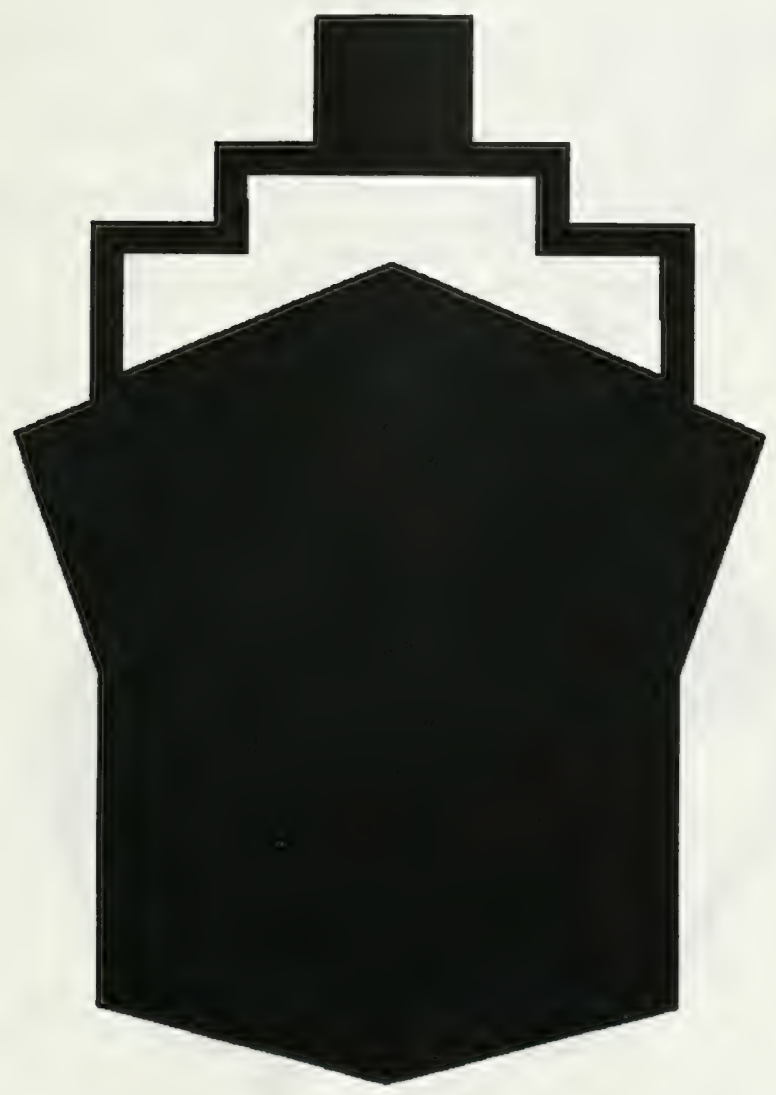

\section{F-5 VOTING}

Delegates in favor (86):

Adelmann, Aitken, Bamberger, Barkley, Beck, Becker, Beezhold, Bishop, Black, Bower, Brueckner, Buenting, Bullard, Bunt, Byrns, Caffee, Campbell, Carey, Coates, Crawford, Deneen, Dickev, Eichelkraut, Eyre, Falco Gabriel, Graeff, Gross. Gruber, Haertel, Hagan, Hamberg, Hambly, Harney, Hooser, Hunsaker, Jacobs, Jessen, Johnson, Jorstad, Keitzman, Kielsmeier, Konsis, Kutska, Lamb, Lehman, Ludwig, Lymenstull, Marquardt, McAllister, McFarlane, Mickelson, Mittage, Montgomery, A. Morris, Nix, Noe, Norman, Padovan, Peach, Pientka, Platt, Potts, Reardanz, Roehll, Rogers, Rolfe, Schmitt, Schreiber, Schwartz, Shimp, Silberhorn, Skelly, Sliwa, Smith, Spada, Spale, Sparr, Struck, Stumpf, Tetzlaff, Trimble, Turner, Werthwein, White, Young.

Delegates not voting (31): Armer, Baker, Caveny, Desulis, Dirksen, Dougherty, Erickson, Funk, Gale, Garner, Guthrie, Hartman, Kozicky, Lechner, Martin, Mills, R. Morris, Penberthy, Romano, Roth, Siegner, Smithson, Spaniol, J. Stewart, L. Stewart, Veugeler, Walker, Walters, Weirich, Yacalavitch, 


\section{F-7 VOTING}

Delegates in favor (61):

Adelmann, Baker, Barkley, Beck, Beezhold, Bishop, Bower, Bullard, Caffee, Campbell, Carey, Coates, Crawford, Dickey, Eichelkraut, Eyre, Falco, Gabriel, Gale, Hagan, Hamberg, Hambly, Harney, Hartman, Hooser, Jacobs, Johnson, Jorstad, Kielsmeier, Konsis, Kutska, Lehman, Ludivig, Marquardt, McFarlane, Mickelson, Mittage, Montgomery, A. Morris, Norman, Padovan, Platt, Roehll, Rogers, Rolfe, Roth, Schmit, Schreiber, Schwartz, Shimp, Skelly, Sliwa, Smithson, Spada, Spale, Struck, Stumpf, Tetzlaff, Turner, Werthwein, White.

Delegates not voting (56): Aitken, Armer, Bamberger, Becker, Black, Brueckner, Buenting, Bunt, Byrns, Caveny, Deneen, Desulis, Dirksen, Dougherty, Erickson, Funk, Garner, Graeff, Gross, Gruber, Guthrie, Haertel, Hunsaker, Jessen, Keitzman, Kozicky, Lamb, Lechner, Lymenstull, Martin, McAllister, Mills, R. Morris, Nix, Noe, Peach, Penberthy, Pientka, Potts, Reardanz, Romano, Siegner, Silberhorn, Smith, Spaniol, Sparr, J. Stewart, L. Stewart, Trimble, Veugeler, Walker, Walters, Weirich, Yacalavitch, Yanor, Young.

\section{NON-RECYCLED PAPER TAX (F-7)}

Recommendation: The Division of Forest Resources will develop a proposal to create a recycling tax on all non-recycled cut sheet paper, business forms and converted paper sold in Illinois.

This tax will be not less than 1 percent of the retail sales value nor less than 1.5 per cent of the wholesale sales value of these products. An amount not less than $331 / 3$ percent of the annual fiscal year appropriation for the Division of Forest Resources nor less than 25 percent of all monies generated by this recycling tax will be deposited into the Forestry Development Fund to support the Forestry Nursery Program. The remainder of the funds generated will be deposited into the Habitat Endowment Trust Fund.

\section{IDOC RESPONSE:}

From the debate in the Assembly of Delegates, the non-recycled paper tax, which was estimated to generate $\$ 5$ million per year, appeared to confuse a number of delegates. Therefore, the Department analyzed the recommendation and concluded:

1. The use of recycled office paper and recycling technology is increasing without a tax on non-recycled paper; therefore, the tax would generate ever diminishing revenues.

2. Collection of the tax would be difficult due to the lack of recycled paper manufacturers and distributors in Illinois and the lack of a clear and accepted definition of recycled paper.

The Department does not endorse recommendation F-7.

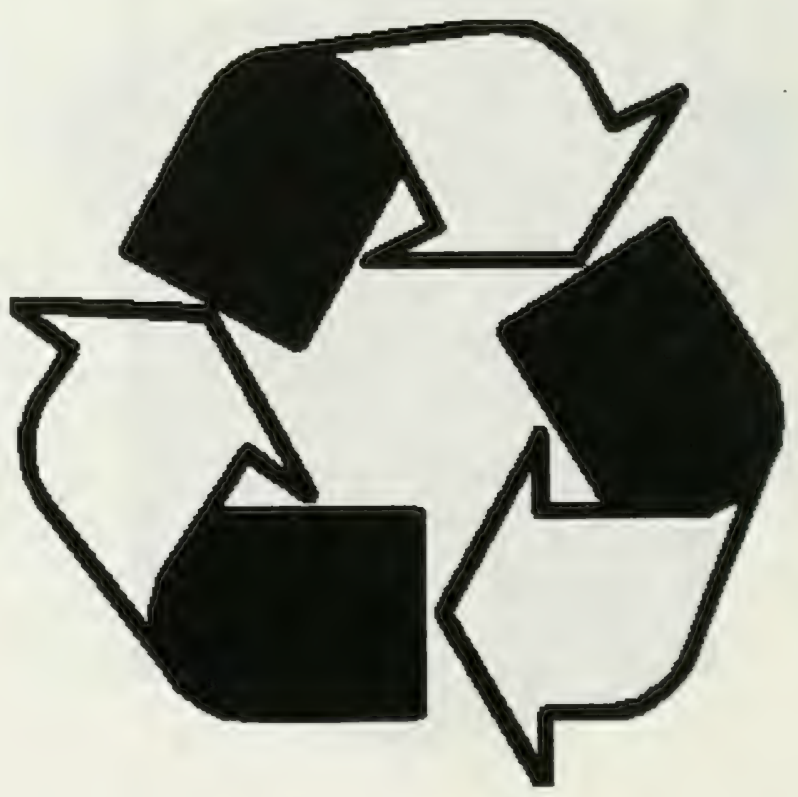




\section{VIDEO/MOVIE TAX (F-8)}

Recommendation: Enact a new five percent state sales tax on video tape rentals and the sale of motion picture admission tickets.

The receipts from these taxes would be designated solely for the development and implementation of conservation education programs, both in-house and for primary and secondary school education programs. A tax of five percent is estimated to yield revenues of approximately $\$ 15$ million to $\$ 16$ million annually. If the natural heritage of the state is to be preserved, protected and enhanced for the benefit and enjoyment of its citizens, it is critical that conservation education be given a high priority and adequate funding.

\section{IDOC RESPONSE:}

Same as response to $\mathrm{F}-1 / 2$.

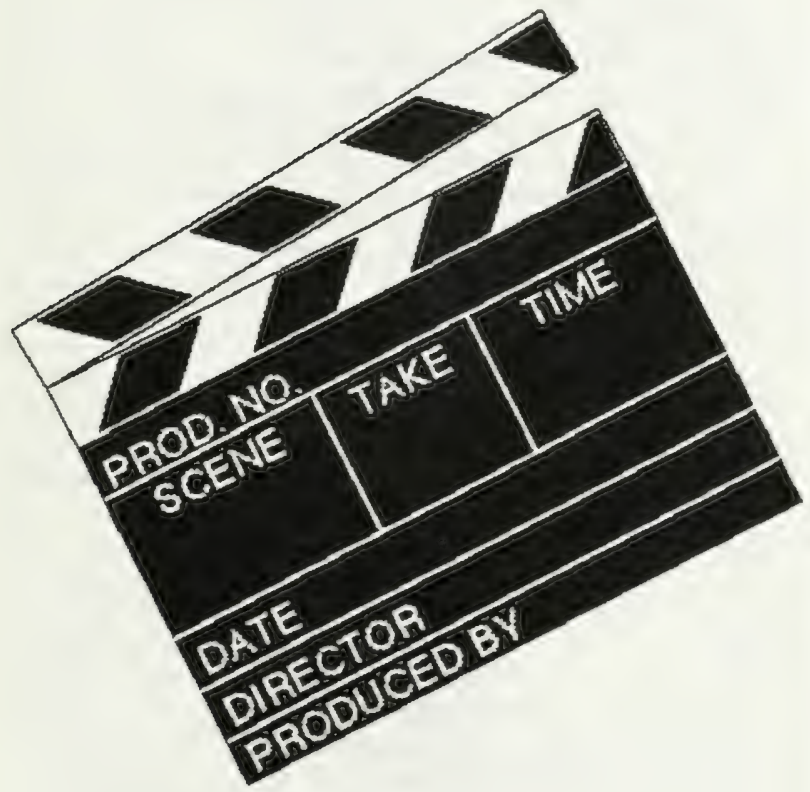

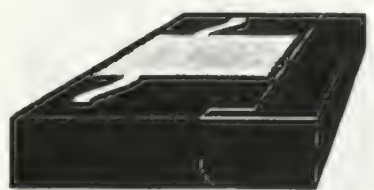

\section{F-8 VOTING}

Delegates in favor (96):

Adelmann, Aitken, Baker, Barkley, Beck, Becker, Beezhold, Bishop, Black, Bower, Brueckner, Buenting, Bullard, Bunt, Caffee, Campbell, Carey, Caveny, Coates Crawford, Deneen, Desulis, Dickey, Dirksen, Eichelkraut, Erickson, Evre, Falco, Gale, Garner, Graeff, Gruber, Hagan, Hambly, Harney, Hartman, Hooser, Hunsaker, Jacobs, Jessen, Johnson, Jorstad, Keitzman, Kielsmeier, Konsis, Kozicky, Kutska, Lamb, Lechner, Lehman, Ludwig, Lymenstull, Marquardt, McFarlane, Mickelson, Mittage, Montgomery, R. Morris, A. Morris, Nix, Noe, Norman, Padovan, Peach, Pientka, Platt, Potts, Reardanz, Roehll, Rogers, Rolfe, Romano, Roth, Schmitt, Schreiber, Schwartz, Shimp, Silberhorn, Skelly, Sliwa, Smith, Smithson, Spada, Spale, Spaniol, Sparr, J. Stewart, Struck, Stumpf, Tetzlaff, Trimble, Turner, Werthwein, White, Yanor, Young.

Delegates not voting (21): Armer, Bamberger, Bvrns, Dougherty, Funk, Gabriel Gross, Guthrie, Haertel, Hamberg. Martin, McAllister, Mills, Penberthy, Siegner, L. Stewart, Veugeler, Walker, Walters, Weirich, Yacalavitch. 


\section{CONSERVATON CONGRESS II DELEGAWES}

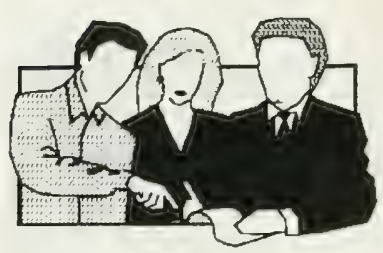

EXECUTIVE COMMITTEE MEMBERS FUNDING COMMITTEE

Representative George Thompson, McHenry

Alternate Judy Beck, Glenview

EDUCATION COMMITTEE

Representative Mary Jo Trimble, Carterville Alternate Gary Rolie, Urbana

OUTDOOR RECREATION COMMITTEE

Representative Bruce Tetzlaff, Cobden

Alternate Monica Young, Woodstock

TRAILS \& GREENWAYS COMMITTEE

Representative John Werthwein, Springfield

Alternate Joyce O'Keefe, Chicago

\section{RESOLUTION I}

\section{Appreciation}

WHEREAS, Director Brent Manning has taken a futuristic concept and developed it into a model for the entire United States, and

WHEREAS, Claudia Emken has tirelessly brought together the many concepts and constituency groups with a contagious enthusiasm which spreads to all who meet her, and

WHEREAS, the many IDOC staff members have given of their own time not only during this week but for the last 18 months, and

WHEREAS, Executive Committee Chairman John Schmitt and his committee have given of their time and energies since the last Conservation Congress,

The delegates of the 1994 Conservation Congress do hereby salute and applaud your dedication and overt efforts to promote harmony, constructive thoughts and actions of our many and varied constituency groups. The plants, animals and citizens of Illinois will reap the benefits not only today but in the future years to come.
RESOURCE MANAGEMENT COMMITTEE

Representative Clark Bullard, Urbana No Alternate

PUBLIC INVOLVEMENT COMMITTEE

Representative Tom Bunt, Carlinville No Alternate

REGION I

Representative Russ Crawford, East Peoria Alternate Warren Gale, Orion

REGION II

Representative John Schmitt, Chicago

Alternate Donna Eyre-Polk, Chicago

REGION III

Representative Edward "Bud" Hooser, Mahomet Alternate Jim Smith, Homer

\section{REGION IV}

Representative Tom Desulis, Frederick

No Alternate

REGION V

Representative Larry Bowman, Marion

No Alternate

DEPARTMENT OF CONSERVATION

Claudia Emken, Springfield

REGIONAL FACILITATORS

REGION I

Randy Nyboer

REGION II

Kurt Bobsin

REGION III

Chris Farris

REGION IV

Mike Cochran

REGION V

Ned Enrietto 


\section{STATEWIDE CONGRESS DELEGATES}

American Fisheries Society - Illinois Chapter: Tom Skelly

Association of Soil and Water Conservation Districts: John Caveny

Audubon Council of Illinois: Russell Johnson

Better Fishing Association of Northern Illinois: Joe Noe

Field Trial Clubs of Illinois, Inc.: E.L. Walters

Great Lakes Sport Fishing Council: Sam Romano

Illinois Arborist Association: Michael Dirksen

Illinois Association of Conservation Districts: Paul Hagan

Illinois Association of Hunting Preserves: Edward Kozicly

Illinois Association of Park Districts: Judy Beck

IIl. Assoc. Resource Conservation \& Development Councils: Dr.

Charles Guthrie

Illinois Association of Snowmobile Clubs: Ron Hambly

Illinois Audubon Society: Marilyn Campbell

Illinois Bass Federation: John Gross

Illinois Bowhunters Society: John Yacalavitch

Illinois Chapter of The Wildlife Society: Daniel Ludwig

Illinois Council on Forestry Development: Gary Rolfe

Illinois Ducks Unlimited: Bud Hooser

Illinois Environmental Council: Gary Struck

Illinois Environmental Education Association: Mary Kelly Lamb

Illinois Good Sam R.V. Orver's Association, Inc.: Chuck Reardanz

Illinois Muskies Alliance: John Weirich

Illinois Native Plant Society: Ken Konsis

Illinois Nurserymen's Association: Chris Lechner

Illinois Park and Recreation Association: Rick Stumpf

Illinois Society of American Foresters: Allan Mickelson

Illinois State Chapter National Wild Turkey Federation: Frank Nix

Illinois State Rifle Association: Kevin Walker

llinois Farm Bureau: Nancy Erickson

Illinois Trailriders: Kandice Haertel

llinois Trappers Association: Lee Stewart

Illinois Tree Farm System: Tom Desulis

Illinois Waterfowlers Alliance: Claude Graef

Illinois Wildlife Federation: Lynn Padovan

Izaak Walton League of America: Richard Eichelkraut

Migratory Waterfowl Hunters, Inc.: Miles Brueckner

Northern Illinois Anglers Association: J.R. Black

Northern Illinois Conservation Club: Arlene Pientka

OpenLands Project: Gerald Adelmann

Pheasants Forever, Inc.: Jeffrey Mills

Quad City Conservation Alliance: Warren Gale

Quail Unlimited: Walter "Max" White

Rails-To-Trails Conservancy - Illinois Chapter: John Werthwein

Salmon Unlimited: Cass Sliwa

Save the Prairie Society: Valerie Spale

Sierra Club, Illinois Chapter: Jack Norman

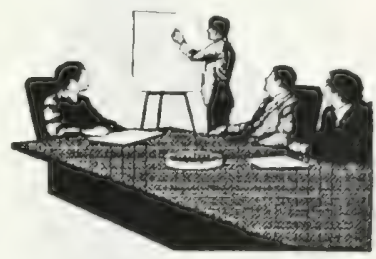

\section{VOLUNTEER NETWORIK}

Recommendation: Create a statewide volunteer network. Identify existing and poten-

tial volunteer groups using

the IDOC Conservation

Congress data base. Existing

IDOC volunteer programs should be expanded and promoted more effectivelv.

Coordinate statewide network goals with constituency groups. Volunteers, in partnership with IDOC, would manage the network at the local level based on policies created jointly by the volunteers and IDOC.

Encourage and train staff to support and participate in the volunteer network.

Use volunteers to educate the public and promote natural resource issues and recreational opportunities.

IDOC response: Current volunteer opportunities at IDOC sites will be identified and a catalog will be developed for constituent use. Regional recognition programs will be developed. A pilot recognition day will be held in April 1995. A directory of volunteers will be published and made available.

Whitetails Unlimited. Inc.: Tom Bunt 
REGIONAL DELEGATES

\section{REGION I}

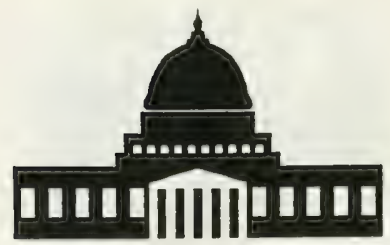

\section{REGIONAX SPECIALISTS}

Recommendation: IDOC should employ, one at a time as funds become available, at least six Conservation Education Specialists, one for each of the five regions and one for Cook County.

The Education Specialists would serve as liaisons between the regional staff, volunteers, public and private education agencies and organizations and public interest groups.

Positions would be added, one by one, as funding becomes available to support the new staff and their operations. Any surplus funds, after the initial six Conservation Education Specialists are hired, shall be used for the development of new materials. Additional outreach efforts and further st aff will be added as warranted.

A source of funding for this Conservation Education Program could be from a specific, dedicated percentage of IDOC's overall budget and/or from a specific, dedicated percentage of all dedicated funding for IDOC programs, existing and future.
Ellen Baker, Franklin Creek Preservation Area Committee, Franklin Grove

+ Ben Bishop, Central Illinois Bowhunters, Canton

Debra Carey, Lee County Natural Area Guardians, Dixon

Russ Crawford, Tri-County Regional Planning Commission, East

Peoria

Jack Dougherty, Split Rock Rod and Gun Club, Ottawa

Bill Jacobs, Natural Land Institute, Rockford

Curtis Jorstad, LaSalle County Soil \& Water Conservation Dis-

trict, Seneca

Moe Kielsmeier, Moe's Bait Shop, Oregon

Pat Martin, Highland Chapter Pheasants Forever, Freeport

Jim McFarlane, Whitetails Unlimited, Rockford

Michael Platt, Heartland Water Resources Council, Peoria.

Bill Siegner, Lake Carroll Fishing Club, Freeport

*DeWayne Silberhorn, Blackhawk Field Archers, Rockford

Dennis Sparr, Putnam County Conservation District, Hennepin

\section{REGION II}

Sandra Bamberger, Trail Riders of DuPage, Clarendon Hills

Bill Barkley, Quad County Hawg Hunters, Muskies Inc, Yorkille

Bill Byrns, The Alliance to Restore the Kankakee River, Bradley

Fran Caffee, Sierra Club, Valley of the Fox Group, Aurora

William Deneen, Southside Muskie Hawks, Blue Island

Donna Eyre-Polk, Chicago Audubon Society, Chicago

Vince Funk, Grundy County Pheasants Forever, Morris

Rick Gabriel, The Nature Conservancy, Chicago

Della Hamberg, Lake County Audubon, Libertyville

Sue Harney, Kane County Natural Area Volunteers, Sleepy Hollow

Don Jessen, Addison Park District, Addison

Ken Kutska, Wheaton Park District, Wheaton

Ronald Lehman, I \& M Canal Natural Heritage Corridor Commission, Channahon

Barbara Marquardt, Fox Valley Land Foundation, Elgin

+ Robert Montgomery, Max McGraw Wildlife Foundation, Dundee Dick Peach, Walleyes Unlimited U.S.A., Evanst on

Janice Roehll, Forest Preserve District of DuPage County, Glen Ellyn

Charles Roth, Thom Creek Audubon Society, Steger

John Schmitt, The Nature of Illinois Foundation, Chicago

Susie Schreiber, Lake-Cook Chapter of The Illinois Audubon Society, Winnetka

Marvin Schwartz, Prairie Woods Audubon Society, Wheeling

Dennis Spada, National German Pointing Dog Association, Monee

+Robert Veugeler, McHenry County Pheasants Forever, Crystal

Lake

Monica Young, Wildlife In Need Foundation, Woodstock

Note: Committee Chairs

+ Work Team Chairs 


\section{CONSER VATION CONGRESS II DELEGATES}

\section{REGIONAL DELEGATES REGION III}

Alicia Admiraal, Grand Prairie Friends of Illinois, Urbana

Shirley Armer, East Central Illinois Pointer \& Setter Club, Champaign

Mary Bower, Fox Ridge Foundation, Charleston

Earl Buenting, Sangamon Valley Ducks Unlimited, Gifford

+Clark Bullard, Committee on the Middle Fork of the Vermilion

River, Inc., Urbana

David Coates, The Nature Conservancy, Decatur

Jim Hunsaker, Illinois Taxidermist Association, Hidalgo

Jane Kietzman, Champaign County Soil \& Water Conservation

District, Champaign

Stan Potts, Central Illinois Whitetails Undimited, Clinton

* Jim Smithson, Illinois Power Company, Decatur

Roland Spaniol, Coles County Soil \& Water Conservation Dis-

trict, Charleston

\section{REGION IV}

Greg Aitken, Southern Illinois Quail Hunters, Sparta

Bob Becker, Illinois Federation of Outdoor Resources, Brighton

+Don Dickey, Illinois Rivers Project, Jerseyville

Charlene Falco, Volunteer Stewardship Network, Springfield

James Garner, Wolf Run Bowhunters, Roodhouse

Helen Gruber, The Nature Institute, Glen Carbon

Allie Lymenstull, Mississippi Valley Hunters \& Fishermans Associa-

tion, Quincy

William McAllister, Macoupin County Farm Bureau, Carlinville

M.J. Rogers, Illinois Archery Association, Carlinville

Sam Smith, Great River Chapter - Illinois Audubon Society, Be-

thalto

Monica Yanor, Lincolnland Volunteer Safety Education Instructors, Chatham

\section{REGION V}

Michael Beezhold, Sociey of Xi Sigma Pi, Omega Chapter, Carterville

+ Miles Hartman, Pulaski-Alexander Soil \& Water Conservation

District, Mounds

Mike Mittage, Southern Illinois Wildlands Project, Carbondale

Alan Morris, Regional Assn. Concemed Environmentalists,

Makanda

Ray Morris, Conservation Coalition, Golconda

John Penberthy, The Nature Conservancy, Ullin

Jody Shimp, Illinois Native Plant Society, Carbondale

+ Bruce Tetzlaff, American Fisheries Society, Cobden

*Mary Jo Trimble, Illinois Regional Brittany Club, Inc., Carterville

Jackie Turner, Shawnee Audubon Society, Creal Springs

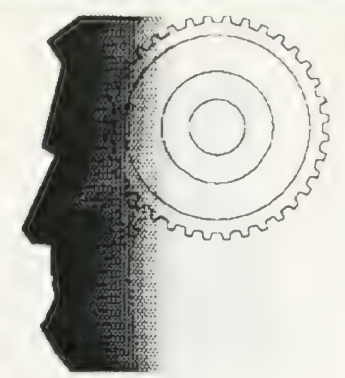

\section{GREENWAY AND TRAIL PLAN}

Recommendation: Establish a process to plan and coordinate statewide greenway and trail development involving the Department, other agencies, organizations and the public.

Implement the process to prepare a comprehensive statewide greenway and trail plan for Illinois. The plan should be sensitive to biological diversity and other natural resources, local concerns, landowner interests, regional geographic features and population density and to compatibility of users; and should serve as "the" plan for guiding acquisition, development and operation of these critical natural resource links and corridors. The current State Trails Plan, the Northeastern Illinois Regional Greenways Plan, the Strategic Plan for the Illinois Department of Conservation and local master plans will serve as a strong start for the Illinois Greenways Plan.

\section{Note: "Committee Chairs \\ + Work Team Chairs}




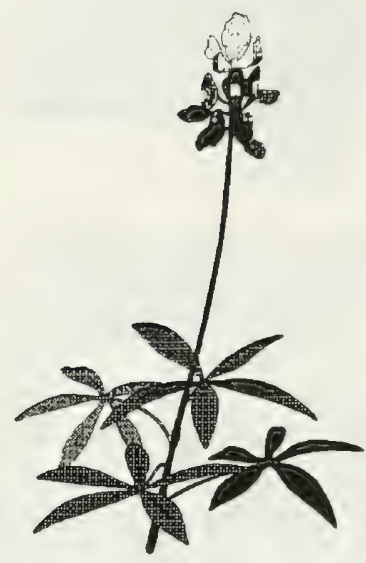

OUTDOOR RECREATION COMMITTEE

Chair: Mary Jo Trimble

Illinois Regional Britanny Club, Inc.

Coordinator: Mike Cochran

Region IV Administrator, Division of Fisheries

Assistants: Rick Messenger

Regional Land Manager, Region IV

Larry Kennedy

Supervisor, Regional Operation Staff

Staff Advisors: Jeff VerSteeg

Division Chief, Wildlife Resources

John Tranquilli

Director, Office of Resource Management

Mike Conlin

Division Chief, Fisheries

Pages: Randall Collins, Linda Ausmus, Lyle Wacaser

\section{LAND MANAGEMENT COMMITTEE}

Chair: John Caveny

Association of Ill. Soil \& Water Conservation Districts

Coordinator: Randy Nyboer

Region I Administrator, Division of Natural Heritage

Assistants: Don McFall

Natural Areas Program Manager

Glen Lyons

Site Superintendent, Fox Ridge State Park

Staff Advisors: Jerry Beverlin

Director, Office of Land Management

Carl Becker

Division Chief, Natural Heritage

Stu Pequignot

Division Chief, Forest Resources

Mike McCully

Administrative Chief, Office of Land Management

Tom Flattery

Manager, Division of Land Acquisition

Pages: Bill Donels, Bob Schanzle, Jean Karnes

\section{EDUCATION COMMITTEE}

Chair: Jim Smithson

Illinois Power Company

Coordinator: Bob Cottingham

Region III Administrator, Division of Wildlife Resources

Assistants: Dave Cassens

Volunteer Services Coordinator, Region II Law Enforcement

Phil Wilson

Education Specialist, Office of Resource Marketing \& Education

Staff Advisors: Kathy Andrews

Chief, Conservation Education

Jim Fulgenzi

Director, Office of Resource Marketing \& Education

Tom Harper

Deputy Chief, Office of Law Enforcement

Pages: Mitch Ingold, Kelly Coleman, Lynette Mick 


\section{PUBLIC INVOLVEMENT COMMITTEE}

Chair: DeWayne Silberhorn

Blackhawk Field Archers

Coordinator: Kurt Bobsin

Region II \& III Administrator, Division of Forest Resources

Assistants: Anne Mueller

Assistant, Office of Public Affairs

Marla Gursh

Wetlands Program, Office of Planning \& Development

Staff Advisors: Diane Hendren

Legislative Liaison

Jay Johnson

Recycling/Internships, Office of the Director

Hurley Harris

EEO Officer, Office of the Director

Meg Bushnell

Northern Illinois Coordinator

Dick Lutz

Manager, Division of Impact Analysis

Pages: Doug Austen, Greg Akers, Noel Laurent

\section{TRAILS \& GREENWAYS COMMITTEE}

Chair: John Werthwein

Rails-To-Trails Conservancy

Coordinator: Ned Enrietto

Landscape Architect, Region V

Assistants: Jim Mick

Impoundments Program Administrator, Division of Fisheries

Mark Yergler

Program Development Supervisor, Division of Grant Administration

Staff Advisors: Bruce Clark

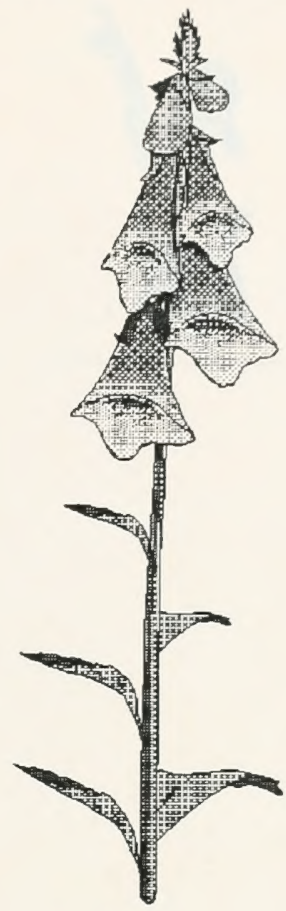

Director, Office of Planning \& Development

Bob Thornberry

Site Planning Supervisor, Office of Planning \& Development

Ron Hallberg

Manager, Division of Grant Administration

Pages: George Bellovics, Stuart Mizuta, Nancy Domst

\section{FUNDING COMMITTEE}

Chair: Judy Beck

Illinois Association of Park Districts

Coordinator: Howard Brewer

Captain, Region II Law Enforcement

Assistants: Rose Ragland

Accounting Supervisor, Office of Budget \& Finance

Mike Sweet

Federal Aid Coordinator, Office of Resource Management

Staff Advisors: Roy Miller

Manager, Office of Budget \& Finance

John Bandy

Budget Section Manager, Office of Budget \& Finance

Brad Hammond

Chief Internal Auditor

Pages: Mick Rosendahl, Cinda Mickelson, Ron Miller 


\section{CONSERVATION CONGRESS FAGITIATORS}

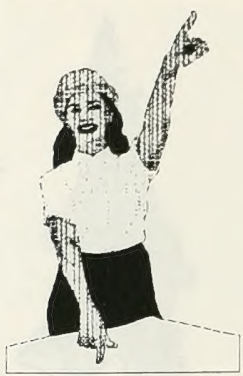

\section{PLANNING TEAM}

Claudia Emken, Constituency Liaison Randy Nyboer, Region I facilitator Kurt Bobsin, Region II facilitator Chris Farris, Region III facilitator Mike Cochran, Region IV facilitator Ned Enrietto, Region $V$ facilitator

Ed Hoffman, Office of Planning and Development Dick Westfall, Office of Planning and Development Jim Garner, Office of Resource Management AnnaMae Ruuttila, Deputy Director's Office

\section{ARRANGEMENTS COMMITTEE}

AnnaMae Ruuttila, Deputy Director's Office Dick Coontz, Public Events and Promotions Ron Allen, Public Events and Promotions Cheryl Gwinn, Office of Resource Marketing and Education John Buehner, Office of Resource Marketing and Edúcation

Sharon Baur, Office of Resource Management

Tammy Britz, Constituency Relations Program Larry Sturm, Office of Land Management Rich Milburn, Office of Administration Lou Matsko, Office of Administration Jill Willis, Office of Law Enforcement

Dave Longo, Office of Resource Management

\section{PUBLICATIONS EDITOR}

John Allen, Northern Illinois Office

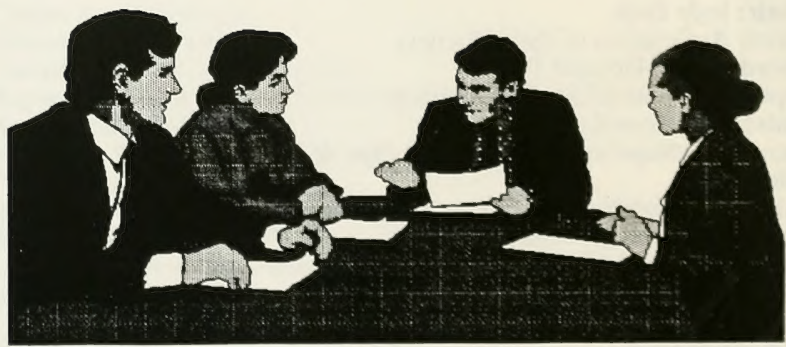


UNIVERSITY OF ILLINOIS-URBANA 333.72M11X COO1
CONSERVATION C.O.N.G.R.E.S.S SPRINGFIEL

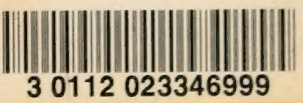

